University of Wollongong

Research Online

Faculty of Business - Papers (Archive)

Faculty of Business and Law

2013

Estimating and forecasting residential electricity demand in Iran

Elham Pourazarm

University of Wollongong, ep934@uowmail.edu.au

Arusha Cooray

University of Wollongong, arusha@uow.edu.au

Follow this and additional works at: https://ro.uow.edu.au/buspapers

Part of the Business Commons

Research Online is the open access institutional repository for the University of Wollongong. For further information contact the UOW Library: research-pubs@uow.edu.au 


\title{
Estimating and forecasting residential electricity demand in Iran
}

\begin{abstract}
This study examines the short- and the long-run relationship between electricity demand and its determinants in the Iranian residential sector. The study employs unit root tests, cointegration and errorcorrection models on annual time series for the period, 1967-2009. The results show that electricity price is insignificant and income elasticity is lower than unity. The most influential factor influencing household electricity demand is cooling degree days. The number of electrified villages (an indicator of economic progress) is statistically significant, showing that economic progress has a positive impact on electricity demand. Electricity demand is forecast until 2020. The results show that under the most probable projection, electricity consumption in the residential sector will grow at an annual rate of $29 \%$ and $80 \%$ by 2014 and 2020, respectively.
\end{abstract}

\section{Keywords}

era2015, demand, electricity, iran, residential, estimating, forecasting

Disciplines

Business

\section{Publication Details}

Pourazarm, E. \& Cooray, A. V. (2013). Estimating and forecasting residential electricity demand in Iran. Economic Modelling, 35 546-558. 


\section{Estimating and Forecasting residential electricity demand in Iran}

\section{Elham Pourazarm ${ }^{a}$, Arusha Cooray ${ }^{b c^{*}}$}

${ }^{a b}$ School of Economics, Faculty of Commerce, University of Wollongong, NSW 2522, Australia; E-mail: arusha@uow.edu.au

${ }^{c}$ Centre for Applied Macroeconomic Analysis, Australian National University;

E-mail: ep934@uowmail.edu.au

*Corresponding author

Acknowledgements: The authors are grateful to Oleg Yerokhin for valuable feedback on the theoretical framework and to Reetu Verma and Charles Harvie for constructive comments. 


\title{
Estimating and Forecasting residential electricity demand in Iran
}

\begin{abstract}
This study examines the short and long-run relationship between electricity demand and its determinants in the Iranian residential sector. The study employs unit root tests, cointegration and error-correction models on annual time series for the period, 1967-2009. The results show that electricity price is insignificant and income elasticity is lower than unity. The most influential factor influencing household electricity demand is cooling degree days. The number of electrified villages (an indicator of economic progress) is statistically significant, showing that economic progress has a positive impact on electricity demand. Electricity demand is forecast until 2020. The results show under the most probable projection, electricity consumption in the residential sector will grow at an annual rate of 29\% and 80\% by 2014 and 2020, respectively.
\end{abstract}

Keywords: Iran; Residential electricity demand; Economic development; Electrified villages; ARDL; Structural breaks; Short- and long-run price and income elasticities.

JEL Codes: C22, C51, D12, Q41, Q43, Q48 


\section{Introduction}

Electricity generation and distribution are controlled by both the private and government sectors in Iran, predominantly the state. Electricity in Iran is subsidized. In order to support and encourage private contribution, electricity generated by the private sector is bought by the state and distributed to final consumers. Currently, the retail electricity price is set by the government and the electricity price at all levels of consumption, is below its production cost (Bureau of Electricity and Energy Planning, 2010, BEEP). The real price of electricity for the residential sector during the sample period experienced over a 95\% decrease from 1967 to 2009 (Figure 1) ${ }^{1}$.

[Figure 1, about here]

Major concerns of Iranian energy policy makers relate to the high growth rate of domestic demand and inefficient use of electricity. Per capita electricity consumption tripled in the last two decades (1990-2010) and the average growth of per capita electricity consumption in Iran (7.9\%) was over two times higher than the global average (3.3\%) (TAVANIR Deputy of Human Resources and Research, 2008, TAVANIR). ${ }^{2}$ These statistics show that if the current growth rate remains unchanged, electricity consumption will double within one decade. Therefore, investigating the issue of electricity demand in Iran is of crucial importance. Table 1 presents historical data for the per capita electricity consumption growth rate from 1975 to 2010. As can be seen the growth rate has been very volatile between 1.5 in 1980 and 15.1 in 1983.

\footnotetext{
1 The reason for such a large decline in real electricity price is the considerable increase in the consumer price index (CPI) after the Islamic revelation. In 2009, the CPI was 586 times higher than that of 1967 and rose from 0.98 to 575.12 (base year 1997).

2 TAVANIR denotes the Management Organization of Iranian Electricity Generation, Transmission, and Distribution.
} 
[Table 1, about here]

Households in many countries account for a large proportion of electricity consumption. The residential sector is the major electricity end user in Iran accounting for $33.2 \%$ of total electricity consumption (IIES, 2010). The equivalent figure for the world and other regions is much lower than that of Iran (BEEP, 2011). ${ }^{3}$ In 2009, household electricity consumption experienced a 41\% increase compared to 1989 and reached 2,803 kWh. The International Energy Agency (IEA) statistics show that per capita electricity consumption in Iran in 2008 was 2,423 and this figure for the world reached 2,782 kWh (IEA, 2010). The large volume of electricity consumption by households is mainly due to the inefficient utilisation of electric appliances (BEEP, 2008). Therefore an investigation of the behaviour of residential end users is essential for policy makers to establish energy policies aimed at persuading consumers toward more efficient utilization of energy.

This paper makes several significant contributions to the analysis of residential electricity demand of the Iranian economy. This is the first study to examine several variables for modelling electricity demand in Iran taking into account features specific to the Iranian power industry such as weather conditions and economic progress. This study forecasts electricity demand (until 2020). Moreover, preveious Iranian studies on residential demand have not employed the Autoregressive Distributed Lag (ARDL) approach, which is consistent with the properties of a small sample (Mah, 2000), or examined the data for structural breaks. This study

\footnotetext{
${ }^{3}$ The residential sector share for the world is $27.4 \%$ and for Asia and Oceania, Central and South America, Eurasia and Africa are 20.6\%, 26.5\%, 26.2\%, 31.4\% respectively.
} 
employs the multiple structural break tests of Lee and Strazicich (2003) and Narayan and Popp (2010).

The rest of this paper is structured as follows. Section 2 reviews the literature. Section 3 presents the theoretical framework. Section 4 details the data and methodology. Section 5 discusses the empirical results; Section 6 forecasts electricity demand until 2020 and Section 7 concludes.

\section{Literature review}

The literature on residential electricity consumption has employed diverse methodologies. See for example, the studies of Flaig (1990) for Germany, Filippini (1999) for Switzerland, Kamerschen and Porter (2004) for the US, Atakhanova and Howie (2007) for Kazakhstan, Narayan et al. (2007) for the G7 countries and Nakajima (2010) for Japan (see Table 2 for a summary of studies). The present study employs unit root tests allowing for multiple structural breaks and the ARDL method. Studies using the time series methods are discussed below.

Flaig (1990) and Narayan et al. (2007) find that income and price elasticities are lower than unity in the short-run suggesting that electricity consumption is inelastic with respect to changes in income and price. Long-run elasticities in the former are lower than unity suggesting that consumers are not responsive to changes in income and electricity price. But in the latter, price elasticity is -1.45 indicating that electricity demand would decrease by $1.45 \%$ if electricity price increases by 1\%. Flaig considers fuel oil and Narayan et al. (2007) gas as substitutes for electricity. In both studies, the coefficients of the considered fuel are positive which confirms the complementarity with electricity. Filippini (1999), Kamerschen and Porter (2004), Atakhanova 
and Howie (2007), and Nakajima (2010) present long-run price and income elasticities. The first two studies show that price and income elasticities are lower than unity. The study of Atakhanova and Howie (2007) shows that price elasticity depending on the method used, varies between -0.22 and -1.10 and income elasticity between 0.12 and 0.59 . Nakajima (2010) finds that price elasticity varies between -1.20 and -1.13 and income elasticity between 0.60 and 0.65 . The number of households and size of household are two significant variables affecting the electricity demand of Swiss households in the study of Filippini (1999) with elasticities of 0.90 and 1.53 for price and income, respectively.

Silk and Joutz (SJ) (1997) use the Johansen and Juselius (1990) methodology, Holtedahl and Joutz (HJ) (2004) apply the Hendry and Juselius (2000; 2001) method and Dergiades and Tsoulfidis (DT) (2008) and Narayan and Smyth (NS) (2005) the ARDL approaches. DT use the critical values (CVs) employed by Narayan (2004). ${ }^{4}$ They show that residential electricity demand has a low sensitivity to price and income changes in the short-run. SJ and NS find that income and price elasticities in the long-run are lower than unity, whereas the studies of DT and HJ find elasticities of -1.60 and 1.04 for price and income respectively. DT and SJ show the coefficients for weather conditions to be statistically significant but lower than unity in the short and long run for the US. HJ finds only cooling degree days to be significant in the short-run for Taiwan. Conversely, NS finds that residential electricity demand within Australia is sensitive to weather conditions in the long-run with an elasticity of 1.69. Both SJ and DT find fuel oil to be a replacement for US residential electricity. HJ incorporate the world price of oil into the model and find that oil is a good alternative for residential electricity in Taiwan. NS consider natural gas. Their results show that natural gas is not a substitute for electricity.

\footnotetext{
${ }^{4}$ Narayan (2004) computed critical values (CVs) for the ARDL approach for sample sizes ranging from 30 to 80, and found that the CVs in Pesaran et al. (2001) are 35\% lower than those found in his research.
} 
HJ (2004) argues that electricity modelling for developing countries could be different to industrialized countries, and introduces a general model for the residential sector. They use the degree of urbanization as a proxy for technological change in the stock of electrical appliances. The results show that urbanization elasticity in the short- and long-run are 1.61 and 3.91, respectively. DT use the occupied stock of houses as a proxy for the stock of electrical appliances. The coefficient for the stock of occupied houses is 1.50 implying a strong impact on the electricity use of households.

The literature on residential electricity demand for developing countries, including Iran is limited. The only investigations of residential electricity demand for Iran have been conducted by Amini Fard and Estedlal (2003) and Askari (2002) which use the Johansen and Juselius (1990) and generalized least squares methods, respectively. In addition to price and income, the latter includes the rate of power outage and the former, dummy variables for the quality of electricity supply and the Iran-Iraq war. The impact of these variables on residential electricity consumption are negative. The short- and long-run price elasticities in the former study are -0.97 and -1.36 while the latter presents own price elasticities of 0 and -0.59 respectively, suggesting that households are not responsive to price. The short- and long-run elasticities for income in the Askari study are 0.11 and 0.16, while in Amini Fard and Estedlal, they are 0 and 0.24 . That is, household electricity demand is not sensitive to changing household income.

Iranian studies have applied the ADF tests, however, they have not taken into account the presence of structural breaks. In the presence of structural breaks, the results from unit root tests can be misleading in terms of the non-stationarity of time series data (Perron, 1989). In addition, the use of traditional cointegration methods on small samples can lead to small sample size bias 
and the results obtained from these studies could be unreliable. Therefore the present study corrects for this by taking into account structural breaks.

As seen in Table 2 all studies have investigated the impacts of price and income on electricity demand of households. Few studies have considered the effect of weather conditions and the price of substitute energy for electricity. In a limited number of studies electricity and income have elasticities higher than unity (see the studies of Beenstock et al. (1999), Holtedahl and Joutz (2004) and Zachariadis \& Pashourtidou (2007)). The majority of studies have found electricity demand inelastic with respect to income and electricity price.

[Table 2, about here]

\section{Theoretical framework}

The theoretical foundation of studies on residential electricity demand, are mainly based on theories of consumer behaviour. ${ }^{5}$ Here, electricity is a good which has direct effects on consumer utility. Maximization of consumer utility subject to a budget constraint, taking the first derivative and solving the system of equations will yield the demand for electricity and other commodities. If the demand function is characterised by a constant elasticity of demand, then the total electricity demand of all consumers at time $t$ will be a function of price of electricity, substitute

\footnotetext{
${ }^{5}$ The theoretical foundation also can be based on a household production function which presents electricity as a good which is purchased by households in the market and combined with a capital stock of appliances to produce an electric composite commodity (Dubin, 1985; Flaig, 1990). Electricity impacts consumer utility indirectly and through electric composite goods. Electricity demand is derived as a function of the price of composite goods produced by households (such as food), the price of electrical appliances, energy price, income, price of substitute energy. Due to the lack of data for the price of composite goods the majority of studies analyse residential electricity demand in the context of consumer behaviour theory.
} 
and other goods, consumer income and geographical and demographic factors. Taking the log transformation of the electricity demand function results in: ${ }^{6}$

$$
q_{t}=\alpha p_{e t}+\beta p_{s t}+\tau p_{x t}+\gamma y_{t}+\delta g_{t}
$$

where the $q_{t}, p_{e t}, p_{s t}, p_{x t}, y_{t}$ and $g_{t}$ display the log values of the electricity demand, price of electricity, substitute and other goods, consumer income and geographical factors respectively.

Rapid development can be another factor influencing electricity demand in developing countries (Halicioglu, 2007; Holtedahl \& Joutz, 2004). In addition, considering that households use electricity for air conditioning it is expected that variations in temperature may impact residential electricity demand. Therefore, inserting a weather variable to the model is important. Deriving a composite price for other goods $\left(p_{x t}\right)$ is generally difficult particularly in the case of Iran where data is limited. Moreover, changes in price of other goods do not play a significant role in the consumption of electricity by households due to two reasons. First electricity cost share in the total expenditure of an Iranian household is very low (between 0.5 to 1.7\% (BEEP, 2011) and second, electricity is an essential service for households. Therefore, considering the low sample size of this study and in order to save degrees of freedom, $p_{x t}$ is omitted from the residential model. The modified model is redefined as:

$q_{t}=\alpha p_{e t}+\beta p_{s t}+\gamma y_{t}+\theta e_{t}+\eta w_{t}$

where $e$ and $w$ represent economic progress and weather conditions. Other variable definitions are the same as for Equation (1).

\footnotetext{
${ }^{6}$ Appendix A contains details of obtaining the demand function.
} 


\section{Data and Econometric Methodology}

This analysis relies on annual observations from 1967 to 2009. The following variables are used in the study. The influence of household income on electricity consumption is proxied by final fixed expenditure of household consumption $(h c o)^{7}$. Development can increase the social wellbeing of people by providing critical infrastructure such as electricity. Therefore, the number of electrified villages $(n v)$ is used as a proxy for economic progress. Cooling degree days $(c d)$ is used to test for the effects of weather on electricity demand. A one degree $c d$ shows that the outside temperature is one degree higher than the base temperature $\left(21^{\mathrm{oC}}\right)$. The annual index is an accumulation of daily indices. In the current paper $c d$ for the overall country is obtained by summing the results for 25 cities.

The series used in the study are residential electricity demand (cr), residential electricity price (epr), residential natural gas price ( $g p)$, final fixed expenditure of households ( $h c o$ ), number of electrified villages $(n v)$ and cooling degree days $(c d)$. The data are collected from TAVANIR, the Ministry of Petroleum and the climate factors from the Iranian Meteorological Organization and the Iranian Central Bank. The nominal data have been deflated using CPI with 1997 as the base year. All data series are converted into logarithmic form for the empirical analysis.

Dickey and Fuller developed a unit root test (1981, ADF) to study the time series properties of the data. Perron (1989) showed that the ADF test may be biased in favour of non-

\footnotetext{
${ }^{7}$ Initially, income was considered in the model, but the estimated coefficient was negative, which might have been due to unreliability and low accuracy of data for household income. This is possibly because, households do not express their real income due to safety issues. Therefore, final fixed expenditure is used. Additionally, a theoretical justification for this can be found in the Permanent Income Hypothesis which suggests that consumption is a good measure of expected permanent income.
} 
rejection of the null hypothesis of a unit root when the series has a structural break. Lee and Strazicich (LS) (2003) argued that rejection of the null hypothesis of the ADF-type tests ${ }^{8}$ implied rejection of a unit root without breaks rather than rejection of unit roots per se. Under the LS (2003) tests structural breaks are allowed under the null and alternative hypotheses and the results remain unaffected by breaks under the unit root null hypothesis.

Since the 1970's, several political and economic incidents (such as the Islamic revolution and the Iran-Iraq war) have occurred which may have affected the macroeconomic series and consequently the microeconomic data including the applied series used in this research. Therefore, it seems important to check the time series for stationarity and structural breaks. In this research the stationarity of the applied series are examined using the ADF, LS and NP tests. The ADF test is based on the following regression:

$\Delta y_{t}=\alpha y_{t-1}+\sum_{i=1}^{k} \beta_{i} \Delta y_{t-i}+x_{t}^{\prime} \gamma+u_{t}$

where $y$ is the time series being tested for a unit root at time $t$ and $T$ is the number of observations. $x_{t}$ is the exogenous variable (a constant or a constant and trend). $\Delta$ denotes the first difference operator and $u_{t}$ is an i.i.d error term. Following Engle and Yoo (1987) the Akaike information criterion (AIC) is used to determine the optimal lags.

The LS test statistic is the $t$-statistic of $\alpha$ in Equation (4):

$\Delta y_{t}=\delta^{\prime} \Delta Z_{t}+\alpha \tilde{y}_{t-1}+\sum \Delta \tilde{y}_{t-i}+u_{t} ; \tilde{y}_{t}=y_{t}-\tilde{\psi}_{x}-Z_{t} \tilde{\delta} ; \tilde{\psi}_{x}=y_{1}-Z_{1} \tilde{\delta}$

Where $Z_{t}$ is a vector of exogenous variables, $\delta^{\prime}$ is the corresponding parameters of the vector. LS defined Model AA capturing two breaks in the level and $Z_{t}=\left[1, t, D U_{i t}\right]^{\prime}$ and Model CC capturing

\footnotetext{
${ }^{8}$ ADF-type tests such as Zivot and Andrews (1992) and Lumsdaine and Papell (1997) tests are derived under the null hypothesis of a unit root without break(s).
} 
two breaks in the level and trend and $Z=\left[1, t, D U_{i t}, D T_{i t}\right]^{\prime}$. Where, $D U_{i t}$ are dummy variables capturing breaks in the level and $D T_{i t}$ are breaks in the level and trend, respectively. $D U_{i t}$ and $D T_{i t}$ are one and $t-T b_{i}$, respectively if $t \geq T b_{i}+1$ and zero otherwise $(i=1,2) \cdot \tilde{y}$ is the detrended value (following Schmidt and Phillips (1992)). $\tilde{\delta}$ are the coefficients in the regression of $\Delta y_{t}$ on $\Delta Z_{t} . \Delta \tilde{y}_{t-i}$ corrects for the presence of autocorrelated disturbances. The optimal lag length is selected by applying the general-to-specific method proposed by Ng and Perron (1995).

As was mentioned LS (2001; 2003) argued that the results of the ADF-type unit root tests, in the presence of a break may be biased. Narayan and Popp (2010) solved this problem and introduced models M1 and M2 which allow two breaks in the level and two breaks in the level and trend. The NP test is based on the following equations:

$$
\begin{aligned}
& y_{t}^{M 1}=\rho y_{t-1}+\alpha_{1}+\beta^{\prime} t+\sum \theta_{i} D\left(T b^{\prime}\right)_{i t}+\sum \delta_{i} D U_{i t-1}^{\prime}+\sum_{j=1}^{k} \beta_{j}^{\prime} \Delta y_{t-j}+e_{t}^{\prime} \\
& y_{t}^{M 2}=\rho y_{t-1}+\alpha_{1}^{\prime}+\beta^{\prime \prime} t+\sum k_{i} D\left(T b^{\prime}\right)_{i t}+\sum \delta_{i}^{\prime} D U_{i t-1}^{\prime}+\sum \gamma_{i}^{\prime} D T_{i t-1}^{\prime}+\sum_{j=1}^{k} \beta_{j}^{\prime \prime} \Delta y_{t-j}+e_{t}^{\prime \prime}
\end{aligned}
$$

where $T b^{\prime}{ }_{i t}$ are the break dates, $i=1,2 . D U_{i t}$ and $D T_{i t}$ are one and $t-T b_{i}$, respectively if $t>T b_{i}$ and zero otherwise. $D\left(T b_{i}^{\prime}\right)$ is one if $t=T b_{i}+1$ and zero otherwise. The $t$-statistic of $\rho$ is used to test the null hypothesis of a unit root with two breaks $\left(H_{0}: \rho=1\right)$ against the alternative hypotheses $\left(H_{1}: \rho<1\right)$.

The Autoregressive Distributed Lags (ARDL) method is suited for a small sample such as the current research. This approach can be used for a mix of I(1) and I(0) regressors along with the structural break elements in the model. Following Pesaran and Pesaran's (2001) approach, this study estimates an unrestricted error correction model applying the OLS method: 


$$
\begin{aligned}
& \Delta c r_{t}=c_{0}+\sum_{i=1}^{p} c_{1 i} \Delta c r_{t-i}+\sum_{i=0}^{q_{1}} c_{2 i} \Delta e p r_{t-i}+\sum_{i=0}^{q_{2}} c_{3 i} \Delta g p_{t-i}+\sum_{i=0}^{q_{3}} c_{4 i} \Delta h c o_{t-i}+\sum_{i=0}^{q_{4}} c_{5 i} \Delta n v_{t-i}+ \\
& \sum_{i=0}^{q_{5}} c_{6 i} \Delta c d_{t-i}+\lambda_{1} c r_{t-1}+\lambda_{2} e p r_{t-1}+\lambda_{3} g p_{t-1}+\lambda_{4} h c o_{t-1}+\lambda_{5} n v_{t-1}+\lambda_{6} c d_{t-1}+\eta D U M_{j}+\varepsilon_{t}
\end{aligned}
$$

where $i$ is the number of the optimal lag. The maximum number of lags for yearly data is two lags (Pesaran \& Shin, 1999). DUM is the vector of deterministic components of structural breaks $(j=1,2)$. In the ARDL method the null hypothesis is that there is no long-run relationship between the variables $\left(H_{0}: \lambda_{1}=\lambda_{2}=\lambda_{3}=\lambda_{4}=\lambda_{5}=\lambda_{6}=\eta=0\right)$. If the $F$-statistic falls outside of the upper bound the null hypothesis is rejected and a long-run relationship exists. If cointegration is detected the following regression estimates the long-run equilibrium:

$$
\begin{aligned}
c r_{t}= & a_{0}+\sum_{i=1}^{k} a_{1} c r_{t-i}+\sum_{i=0}^{l} a_{2} e p r_{t}+\sum_{i=0}^{m} a_{3} g p_{t}+\sum_{i=0}^{n} a_{4} h c o_{t-i} \\
& +\sum_{i=0}^{p} a_{5} n v_{t-i}+\sum_{i=0}^{r} a_{6} c d_{t-i}+\alpha_{7} D U M_{j}+\kappa_{t}
\end{aligned}
$$

Considering that the determinants of residential electricity demand are microeconomic data, which theoretically do not play a significant role for each other, we do not expect to detect more than one cointegrating relationship. Although, Inder (1993) argues that the endogeneity bias in the ARDL models is minimal, in this study to examine the endogeneity of the regressors the Hausman (1978) test is used. The short-run model is constructed on the error correction term $(\text { ecm })^{9}$ derived from the long-run model as follow:

$$
\begin{aligned}
\Delta c r_{t}= & \beta_{0}+\sum_{i=1}^{k} \beta_{1} \Delta c r_{t-i}+\sum_{i=0}^{l} \beta_{2} \Delta e p r_{t}+\sum_{i=0}^{m} \beta_{3} \Delta g p_{t}+\sum_{i=0}^{n} \beta_{4} \Delta h c o_{t-i} \\
& +\sum_{i=0}^{p} \beta_{5} \Delta n v_{t-i}+\sum_{i=0}^{r} \beta_{6} \Delta c d_{t-i}+\beta_{7} e c m_{t-1}+\mu_{t}
\end{aligned}
$$

\footnotetext{
$9 e c m=c r_{t}-a_{0}-\sum_{i=1}^{k} a_{1} c r_{t-i}-\sum_{i=0}^{l} a_{2} e p r_{t}-\sum_{i=0}^{m} a_{3} g p_{t}-\sum_{i=0}^{n} a_{4} h c O_{t-i}-\sum_{i=0}^{p} a_{5} n v_{t-i}-\sum_{i=0}^{r} a_{6} c d_{t-i}-\alpha_{7} D U M_{j}$.
} 


\section{Results and Discussion}

The results of unit root tests show that only cooling degree days is I(0) based on the ADF test while, the results of the LS unit root test ${ }^{10}$ show that all series are $\mathrm{I}(0)$ except electricity price. This could be due to a large change in the real price of residential electricity (over 95\% declines) during the sample period (see Figure 1). Based on the NP test, residential electricity demand, number of villages and cooling degree days are I(0) (see Table 3). The ADF and NP tests do not reject the null hypothesis of unit root for five and three series respectively, while the LS test does not reject the null hypothesis only for one series. These contradictory results among different unit root tests can be due to the tendency of the ADF-type tests not to reject the null hypothesis of a unit root as argued by Perron (1989). The LS and NP tests detect two breaks for all series of interest. However, the break dates reported by the tests are identical in a few cases (shown in bold). Considering the possibility of under rejection of the null hypothesis by the NP test, the LS test will be considered for estimation of the models of electricity demand. The breaks for electricity consumption occurred in 1980 and 1990 based on the LS test. The former break is the start of the Iran-Iraq war and the latter date the post-war reconstruction period.

\section{[Table 3, about here]}

As seen, the variables under consideration are of order $\mathrm{I}(0)$ and $\mathrm{I}(1)$. This confirms that the ARDL approach, which applies I(1) and I(0) series in the models, is an appropriate technique in the case of this research. In addition, the LS unit root test finds that residential electricity demand has two significant breaks and this is another reason for using the ARDL method. However this variable is stationary which confirms that the transitory impacts of the breaks

\footnotetext{
${ }^{10}$ The trimmed region is [0.1T, $\left.0.9 \mathrm{~T}\right]$.
} 
should be examined when modelling electricity demand. The ARDL method allows for inclusion of two dummy variables relevant to the break dates, to take into account the impacts of structural breaks on the system.

The computed F-statistic is 3.92 which is greater than the upper bound value at the $10 \%$ significance level suggesting that there is a long-run relationship between the series of interest. ${ }^{11}$ Table 4 presents the results of the long-run equation.

[Table 4, about here]

The insignificant variables are price of electricity and natural gas. Long-run price and income elasticities are zero and 0.58, respectively, which implies that households are not responsive to changes in income. This result is expected because electricity is a basic commodity for households. Moreover, the low price of electricity may be another reason for the insensitivity of household electricity consumption to changes in electricity price.

The most influential factor on residential sector electricity demand is cooling degree days indicating that the amount of electricity used for cooling buildings is considerable. Another factor impacting electricity demand is the number of electrified villages, an indicator of

${ }^{11}$ Evidence shows that electricity consumption from many years ago does not impact the demand for electricity in the current year. Therefore, Pesaran et al. (1999) recommend a maximum number of two lags for annual data. The SBC and AIC were used to define the order of the ARDL model but the results presented by the AIC gave a better estimation. 
economic progress. ${ }^{12}$ This implies that there is a positive and statistically significant relationship between residential electricity consumption and economic progress.

The results show that natural gas is not a substitute for electricity in the residential sector. This inference is not unexpected because electricity is mainly used for lighting, air conditioning, and electrical appliances and none of the other fuels can be used for these purposes. ${ }^{13}$ The relevant dummy variables have no explanatory power and have unfavourable impacts on the diagnostic tests, and so were omitted from the model. This is not an unexpected result as the inferences of the LS and NP unit root tests show that residential electricity demand is I(0). That is, the impacts of shocks on this variable are transitory. ${ }^{14}$

The short-run model for residential electricity demand is given in Table 5.

[Table 5, about here]

Consumption of residential electricity in the short-run is mainly impacted by the growth rate of household expenditure and weather conditions. The short-run elasticities of price and income are insignificant. These results are reasonable given the contradictory results in unit root tests.

${ }^{12}$ Urbanization and literacy rates were used in the model as proxies for economic development, but the model including the number of electrified villages gave a better result. An issue arises regarding the direction of causality which can run from electricity demand to the number of electrified villages, as growth in electricity demand could be assumed to be a determining factor of the extent to which rural electrification projects are carried out. This is examined by applying the Durbin-Wu-Hausman exogeneity test (Table 7). The result shows that the causal relationship is not from electricity consumption to the number of electrified villages. Moreover, considering the fact that providing infrastructure such as electricity mainly depends on government funding resources, therefore, it is not expected that electricity demand impacts the number of electrified villages.

${ }^{13}$ Kerosene and liquid gas were tested as the substitutes for electricity but no relationship was detected.

${ }^{14}$ Fisher \& Keysen (1962) argued that the stock of electrical appliances is another factor that could be considered in electricity demand modelling. In this study total annual final expenditure on home durable goods was examined in the model as a proxy for this variable. The applied proxy did not demonstrate the expected results and reduced the reliability of the estimated model; thus, it was omitted from the model. 
Additionally, households take time to respond to changes in electricity price and income, changes in preferences and habits, and replace old electrical appliances with more modern and electricity efficient ones. The coefficient on the error correction term is -0.21 suggesting that $21 \%$ of any disequilibrium is adjusted each year. That is, the full convergence process to its equilibrium occurs after about 4.8 years.

The long- and short-run equations pass the standard diagnostic tests for autocorrelation (Durbin and Watson 1950; 1951), functional form (Ramsey 1969), normality (Jarque and Bera, 1980) and heteroskedasticity (Koenker 1981) at the 5\% level. The cumulative sum (CUSUM), the cumulative sum of squares (CUSUMSQ) and Quandt-Andrews (Andrews 1993; Hansen 1993; Quandt 1960) tests are applied to determine whether the functions are stable over time. As seen in Figure 2 the CUSUM and CUSUMSQ tests reveal that the coefficients of the models during the sample period of the study are stable, with the two statistics falling within the $5 \%$ critical bounds. The results of the Quandt-Andrews test confirm the stability of the parameters. As seen in Table 6 the null hypothesis of no breakpoints within trimmed data cannot be rejected by any of the statistics.

[Figure 2, about here]

[Table 6, about here]

The estimated long-run model is examined for the presence of endogeneity. The results of the Wu-Hausman statistic tests show that the null hypothesis of exogeneity cannot be rejected for any of the regressors (See Table 7). The Wu-Haushman statistic is the F-statistic which is 1.62. 
As seen in the table the t-ratio of all exogenous variables suggest that the hypothesis of exogeneity cannot be rejected.

[Table 7, about here]

\section{Residential Electricity Demand Outlook}

\section{0-2014}

Prior to using the models to forecast electricity demand the performance of the estimated equation is evaluated through the one-step-ahead predictor and an in-sample forecast. Under the former, electricity consumption during the sample period is forecast using the estimated model. The forecast and comparison is conducted for the whole sample period rather than what usually is done for the last 5 years of the sample period. Under the latter method, the model is examined with respect to a change in one of the determinants during the sample period. Figure 3 part (a) shows that the forecast moves closely to the actual data and part (b) shows that a $30 \%$ increase in household expenditure results in an increase in electricity demand of the residential sector with changes in accordance with economic theory. Therefore, the model can be used to estimate future residential electricity demand.

[Figure 3 about here]

\section{Scenarios}

To forecast electricity consumption in the years ahead, future values for the exogenous variables should be determined. Applying the most probable cases that may occur for each regressor, nine scenarios are defined to predict residential electricity consumption in Iran from 2010 to 2014 (the years of the Fifth Five-Year Economic, Social and Cultural Plan) and then from 2015 to 2020. 
Iranian energy policy makers aim to remove the implicit energy subsidy by end of $2014 .{ }^{15}$ Three cases for electricity price are defined: High (H), Moderate (M) and Low (L) cases - 66\%, 46\% and $20 \%$. If electricity is generated under non-subsidised fuel for power plants, the retail electricity price should increase by 66\% to reach the electricity generation cost by 2014 and under subsidised fuel $46 \%$. $20 \%$ is chosen because it is a lower percentage than the moderate case. If the energy subsidy were removed, it is expected that household expenditure in the years ahead would increase considerably. Three cases, Low (L), Moderate (M) and High (H) are considered as $6 \%$, $9 \%$ and $12 \% .{ }^{16}$

The growth rate of the price of natural gas is based on the assumption that the price will be equal to the generation cost by 2014 (70\% per year). ${ }^{17}$ Cooling degree days for the years 2010 to 2014 is computed based on the average of each variable in the last five years of the sample period. ${ }^{18}$ The number of electrified villages is based on the announcement of the MOE that in 2010, 646 villages had been electrified, and that $15.2 \%$ of villages with fewer than 20 households do not have access to electricity (TAVANIR, 2011a). This figure represents around 2,143 villages (author's calculations). ${ }^{19}$ Considering the pace of electrification of villages in Iran recently, it can be expected that each year 900 villages are electrified. ${ }^{20}$ Therefore, in 2011 and 2012 the variable is increased by 900 villages. In 2013, the remaining number of villages (343) are added. In 2014 the number of total electrified villages is unchanged, as all villages will have access to electricity by 2013. Figure 4 summarises the forecast assumptions for the annual

\footnotetext{
${ }^{15}$ Details concerning the removal of energy subsidies can be found in the Targeting of Subsidies Plan approved by the Iranian parliament in January 2010.

${ }^{16} 6 \%$ (Low case) is the average growth rate of household expenditure within the sample of this study (1967-2009). 9\% and 12\% are the highest growth rates of household expenditure during the last two decades (1991-2010).

${ }^{17}$ The nominal price of the natural gas price in 2010 remained unchanged from 2009.

${ }^{18}$ Data for these variables are not available for 2010 and 2011.

${ }^{19}$ The total number of villages with fewer than 20 households was 14,100 in 2009 (TAVANIR, 2011a) .

${ }^{20}$ This figure is the average of the number of electrified villages during the last decade (2001-2010).
} 
growth rates of the variables. Scenario LL in the graph corresponds to the low case for electricity price and the low case for household expenditure.

[Figure 4 about here]

Electricity demand from residential households can be forecast using the model for the residential sector and the scenarios described above. Figure 5 shows that electricity demand continues to rise during the forecast period under most scenarios. However, in some graphs the slope of electricity demand seems to be zero or very close to zero. Table 8 confirms the negative trend of electricity demand in 2014 under most scenarios. In scenarios ML, HL and HM, residential electricity use will decline by 1\%, 2\% and 1\% by 2014 respectively, while under other scenarios it will rise by $2 \%$ to $3 \%$. Two scenarios, LL and MM, cause a zero growth rate of electricity demand by the end of the forecast period.

The demand projections show that residential electricity demand in 2014 varies between 64,749 (in the HL scenario) and 77,982 GWh (in the LH scenario). Low-cost electricity does not change electricity demand in the sector significantly, so it is not appropriate from an energy conservation standpoint. In this case there is an increase of $19 \%$ to $34 \%$ in residential electricity demand compared to 2009. Inefficient electricity demand by residential users and a high discrepancy between electricity price and production cost results in higher electricity demand. The high electricity price case seems unrealistic, as it gives a very high annual growth in household electricity price (66\%). Therefore, the moderate case for electricity price seems the most plausible. 
In the case of household expenditure, it is expected that the removal of the energy subsidy and economic sanctions will escalate household expenses significantly. That is, the high electricity price case for household expenditure appears to be the most plausible case. Therefore, the most viable scenario is that of MH. Under these demand projections, electricity use increases from 58,101 GWh in 2009 to 74,849 in 2014, the annual growth rate is cut from $8 \%$ to $2 \%$ in 2014, and the electricity demand of households rises by 29\% compared with 2009 .

[Figure 5 and Table 8 about here]

\section{5-2020}

Applying the most probable scenario (MH) and models estimated in this study, the residential electricity demand outlook during the period 2015 to 2020 is estimated. The assumptions for electricity price for the period 2015 to 2020 is that it increases until it reaches the production cost level (non-subsidised fuel for power plants), remaining fixed thereafter. Table 9 illustrates the forecast of residential electricity demand estimated by this study and during 2010 and 2020. The actual residential electricity demand in 2010 was 62,525 GWh (TAVANIR, 2011b), which is very close to the forecast of this study. The results show that residential electricity demand will increase by 80\% compared to 2009 and will reach 104,548 GWh by 2020 .

[Table 9 about here]

\section{Conclusions}

The estimated model illustrates the influential factors which may be used to assist policy makers in devising appropriate energy policies for Iran. Temperature has the strongest effect on electricity demand in the residential sector. Weather proofing buildings and replacing old coolers 
with modern air conditioners would be feasible solutions for reducing power consumption considerably. The state could offer financial incentives such as interest rate discounted loans to families. The significance of household income shows that electricity taxation can be used to manage electricity demand. Given the large number of low income households, taxation should be applied with caution. The number of electrified villages is another factor influencing residential electricity demand. This shows that it is necessary to provide rural electricity through solar systems rather than through power plants, so that the state can play an important role in assisting rural households to install solar systems. The zero price elasticity of electricity confirms the inefficiency of previous electricity pricing and the importance of modifying pricing policy. Due to the high level of electricity consumption by rich households the suggestion is that the electricity price for high usage electricity consumers is set significantly higher than the electricity price for low electricity usage consumers.

The results of forecasts revealed that electricity demand in the residential sector will continue rising until 2020 under the most probable scenario. If the government relies only on the implementation of the Fifth Plan they need to expand the current capacity by $80 \%$ compared to 2009 to cover electricity demand of households by 2020. This shows the necessity of long-run planning of capacities expansion to cover electricity demand of households and efficient and effective energy policy making along with the implementation of the Fifth Five-Year Economic, Social and Cultural Plan to be able to meet future demand. Plans are underway to increase the role of the private sector in electricity distribution and generation which might ease the problem to some extent. This however, will take time. 


\section{References}

Amini Fard, A \& Estedlal, S 2003, 'Estimation of residential demand for electricity in Iran, evidence from a cointegration approach' (in Farsi)', 18th International Power System Conference, Tehran.

Andrews, DWK 1993, 'Tests for Parameter Instability and Structural Change with Unknown Change Point', Econometrica, vol. 59, pp. 817-858.

Arellano, M \& Bond, S 1991, 'Some Tests of Specification for Panel Data: Monte Carlo Evidence and an Application to Employment Equations', The Review of Economic Studies, vol. 58, no. 2, pp. 277-297.

Askari, A 2002, 'Estimation of Electricity Demand for Residential Sector and Its Price and Income Elasticities' (in Farsi)", The Journal of Barnameh Va Budjeh, vol. 63, p. 103.

Atakhanova, Z \& Howie, P 2007, 'Electricity Demand in Kazakhstan', Energy Policy, vol. 35, no. 7, pp. 3729-3743.

Balestra, P \& Nerlove, M 1966, 'Pooling Cross Section and Time Series Data in the Estimation of A Dynamic Model: The Demand For Natural Gas', Econometrica, vol. 34, no. 3, pp. 585-612.

Beenstock, M, Goldin, E \& Nabot, D 1999, 'The Demand for Electricity in Israel', Energy Economics, vol. 21, no. 2, pp. 168-183.

Breitung, J 2000, 'The Local Power of Some Unit Root Tests for Panel Data', in BH Baltagi (Ed.), Nonstationary Panels, Panel Cointegration and Dynamic Panels, Elsevier Science, New York/Amsterdam.

Bureau of Electricity and Energy Planning 2008, 'Iran Energy Balance 2007', Deputy of Electricity and Energy, Ministry of Energy, Tehran.

Bureau of Electricity and Energy Planning 2010, 'Iran Energy Balance 2008', Deputy of Electricity and Energy, Ministry of Energy, Tehran.

Bureau of Electricity and Energy Planning 2011, 'Iran Energy Balance 2009', Deputy of Electricity and Energy, Ministry of Energy, Tehran.

Central Bank of Iran 2010, accessed 20/8/2011, http://www.cbi.ir/default.aspx.

Dergiades, T \& Tsoulfidis, L 2008, 'Estimating Residential Demand for Electricity in the United States, 1965-2006', Energy Economics, vol. 30, no. 5, pp. 2722-2730.

Dickey, DA \& Fuller, WA 1981, 'Likelihood Ratio Statistics for Autoregressive Time Series with a Unit Root', Econometrica, vol. 49, no. 4, pp. 1057-1072. 
Dickey, DA, Hasza, DP \& Fuller, WA 1984, 'Testing for Unit Roots in Seasonal Time Series', Journal of the American Statistical Association, vol. 79, no. 386, pp. 355-367.

Dubin, JA 1985, Consumer Durable Choice and the Demand for Electricity, North Holland, Amsterdam.

Durbin J. \& Watson G. S. 1950, 'Testing for Correlation in Least Squares Regressions I', Biometrika, vol. 37, pp. 409-428.

Durbin J. \& Watson G. S. 1951, 'Testing for Correlation in Least Squares Regressions II', Biometrika, vol. 38, pp. 159-178.

Engle, RF \& Yoo, BS 1987, 'Forecasting and Testing in Co-Integrated Systems', Journal of Econometrics, vol. 35, no. 1, pp. 143-159.

Filippini, M 1999, 'Swiss Residential Demand for Electricity', Applied Economics Letters, vol. 6, no. 8, pp. 533-538.

Fisher, F \& Keysen, C 1962, A Study in Econometrics: The Demand for Electricity in the United States, North Holland, Amsterdam.

Flaig, G 1990, 'Household Production and the Short- and Long-Run Demand for Electricity', Energy Economics, vol. 12, no. 2, pp. 116-121.

Hansen, BE 1997, 'Approximate Asymptotic P Values for Structural-Change Tests', Journal of Business and Economic Statistics, vol. 15, pp. 60-67.

Hausman, JA 1978, 'Specification Tests in Econometrics', Econometrica, vol. 46, no. 6, pp. 1251-1271.

Hendry, DF \& Juselius, K 2000, 'Explaining Cointegration Analysis: Part I', The Energy Journal, vol. 21, no. 1, p. 1.

Hendry, DF \& Juselius, K 2001, 'Explaining Cointegration Analysis: Part II', The Energy Journal, vol. 22, no. 1, p. 75.

Holtedahl, P \& Joutz, FL 2004, 'Residential electricity demand in Taiwan', Energy Economics, vol. 26, no. 2, pp. 201-224.

Im, KS, Pesaran, MH \& Shin, Y 2003, 'Testing for Unit Roots in Heterogeneous Panels', Journal of Econometrics, vol. 115, no. 1, pp. 53-74.

Inder, B 1993, 'Estimating Long-Run Relationships in Economics: A Comparison of Different Approaches', Journal of Econometrics, vol. 57, no. 1-3, pp. 53-68.

Institute for International Energy Studies 2010, 'Iran Hydrocarbure Balance 2009', National Iranian Oil Company, Tehran. 
International Energy Agency 2010, 'Key World Energy Statistics', International Energy Agency, Paris.

Jarque C. M. \& Bera, AK 1980, 'Efficient Tests for Normality, Homoscedasticity and Serial Independence of Regression Residuals', Econometric letters, vol. 6, pp. 255-259.

Johansen, S 1988, 'Statistical Analysis of Cointegration Vectors', Journal of Economic Dynamics and Control, vol. 12, no. 2-3, pp. 231-254.

Johansen, S 1991, 'Estimation and Hypothesis Testing of Cointegration Vectors in Gaussian Vector Autoregressive Models', Econometrica, vol. 59, no. 6, pp. 1551-1580.

Johansen, S \& Juselius, K 1990, 'Maximum Likelihood Estimation and Inference on Cointegration: With Applications to the Demand for Money', Oxford Bulletin of Economics \& Statistics, vol. 52, no. 2, pp. 169-210.

Kamerschen, DR \& Porter, DV 2004, 'The Demand for Residential, Industrial and Total Electricity, 1973-1998', Energy Economics, vol. 26, no. 1, pp. 87-100.

Koenker R. 1981, 'A Note on Studentizing a Test for Heteroskedasticity', Journal of Econometrics, vol. 74, pp. 119-147.

Lee, J \& Strazicich, MC 2001, 'Break Point Estimation and Spurious Rejections with Endogenous Unit Root Tests', Oxford Bulletin of Economics \& Statistics, vol. 63, no. 5, p. 535.

Lee, J \& Strazicich, MC 2003, 'Minimum Lagrange Multiplier Unit Root Test with Two Structural Breaks', The Review of Economics and Statistics, vol. 85, no. 4, pp. 1082-1089.

Levin, A, Lin, C-F \& James Chu, C-S 2002, 'Unit Root Tests in Panel Data: Asymptotic and Finite-Sample Properties', Journal of Econometrics, vol. 108, no. 1, pp. 1-24.

Lumsdaine, RL \& Papell, DH 1997, 'Multiple Trend Breaks and The Unit Root Hypothesis', The review of economics and statistics, vol. 79, no. 2, pp. 212-218.

Maddala, GS \& Shaowen, W 1999, 'A Comparative Study of Unit Root Tests with Panel Data and a New Simple Test', Oxford Bulletin of Economics \& Statistics, vol. 61, no. 4, p. 631.

Mah, JS 2000, 'An Empirical Examination of the Disaggregated Import Demand of Korea -The Case of Information Technology Products', Journal of Asian Economics, vol. 11, no. 2, p. 237.

Nakajima, T 2010, 'The Residential Demand for Electricity in Japan: An Examination Using Empirical Panel Analysis Techniques', Journal of Asian Economics, vol. 21, no. 4, pp. 412-420. 
Narayan, PK 2004, 'Reformulating Critical Values for the Bounds F-Statistics Approach to Cointegration: An Application to the Tourism Demand Model for Fiji', Economics, Monash University, Melbourne.

Narayan, PK \& Popp, S 2010, 'A New Unit Root Test with Two Structural Breaks in Level and Slope at Unknown Time', Journal of Applied Statistics, vol. 37, no. 9, pp. 1425-1438.

Narayan, PK \& Smyth, R 2005, 'The Residential Demand for Electricity in Australia: An Application of the Bounds Testing Approach to Cointegration', Energy Policy, vol. 33, no. 4, pp. 467-474.

Narayan, PK, Smyth, R \& Prasad, A 2007, 'Electricity Consumption in G7 Countries: A Panel Cointegration Analysis of Residential Demand Elasticities', Energy Policy, vol. 35, no. 9, pp. 4485-4494.

Ng, S \& Perron, P 1995, 'Unit Root Tests in ARMA Models with Data-Dependent Methods for the Selection of the Truncation Lag', Journal of the American Statistical Association, vol. 90, no. 429, pp. 268-281.

Pedroni, P 1999, 'Critical Values for Cointegration Tests in Heterogeneous Panels with Multiple Regressors', Oxford Bulletin of Economics \& Statistics, vol. 61, no. 4, p. 653.

Pedroni, P 2004, 'Panel Cointegration: Asymptotic and Finite Sample Properties of Pooled Time Series Tests with an Application to the PPP Hypothesis', Econometric Theory, vol. 20, no. 03, pp. 597-625.

Perron, P 1989, 'The Great Crash, the Oil Price Shock, and the Unit Root Hypothesis', Econometrica, vol. 57, no. 6, pp. 1361-1401.

Pesaran, HM \& Shin, Y 1999, 'An Autoregressive Distributed Lag Modelling Approach to Cointegration Analysis', in S Storm (Ed.), Econometrics and economic theory in the 20th century: the ranger Frisch centennial symposium, Cambridge University Press, Cambridge.

Phillips, P \& Perron, P 1988, 'Testing for a unit root in time series regression', Biometrika, vol. 75, no. 2, pp. 335-346.

Quandt, RE 1960, 'Tests of Hypotheses that a Linear System Obeys Two Separate Regimes', Journal of the American Statistical Association, vol. 55, pp. 324330.

Ramsey J. B. 1969, 'Tests for Specification Errors in Classical Linear Least Squares Regression Analysis', Journal of the Royal Statistical Society, Series B, vol. 31, pp. 350-371.

Schmidt, P \& Phillips, PCB 1992, 'LM Tests for a Unit Root in the Presence of Deterministic Trends', Oxford Bulletin of Economics \& Statistics, vol. 54, no. 3, pp. 257-287. 
Silk, JI \& Joutz, FL 1997, 'Short and Long-Run Elasticities in US Residential Electricity Demand: A Co-Integration Approach', Energy Economics, vol. 19, no. 4, pp. 493-513.

TAVANIR Deputy of Human Resources and Research 2008, 'Electric Power Industry in Iran 2006-2007', TAVANIR Management Organization, Tehran.

TAVANIR Deputy of Human Resources and Research 2010, 'Statistical Reports on 43 Years of Activities of Iranian Electric Power Industry (1967-2009)', TAVANIR Management Organization, Tehran.

TAVANIR Deputy of Human Resources and Research 2011a, 'Formal Statistics of Electric Power Industry 2010 (Rural)', TAVANIR Management Organization, Tehran.

TAVANIR Deputy of Human Resources and Research 2011b, 'Formal Statistics of Electric Power Industry 2010 (Strategic)', TAVANIR Management Organization,, Tehran.

Wold, H 1974, 'Causal Flows with Latent Variables: Partings of the Ways in the Light of NIPALS Modelling', European Economic Review, vol. 5, no. 1, pp. 67-86.

Zachariadis, T \& Pashourtidou, N 2007, 'An Empirical Analysis of Electricity Consumption in Cyprus', Energy Economics, vol. 29, no. 2, pp. 183-198.

Zivot, E \& Andrews, DWK 1992, 'Further Evidence on the Great Crash, the Oil-Price Shock, and the Unit-Root Hypothesis', Journal of Business \& Economic Statistics, vol. 10, no. 3, p. 251. 
Figure 1: Real price of residential electricity (Rials/KWh)

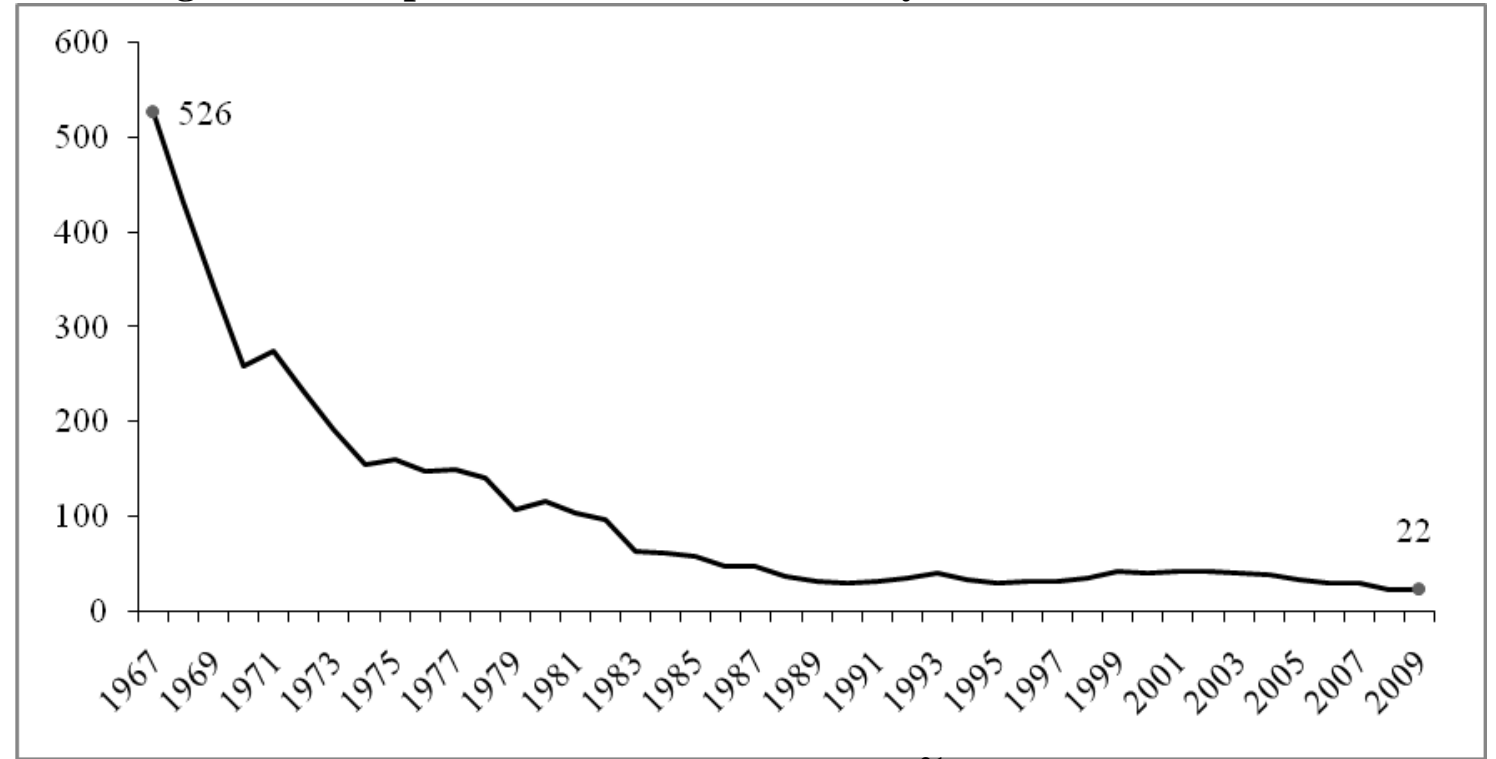

Source: (CBI, 2010; IIES, 2010; author's calculations) ${ }^{21}$.

Table 1: Per Capita and Annual Growth Rate Electricity Consumption in Iran (1975-2010)

\begin{tabular}{|c|c|c|c|c|c|c|c|c|c|c|c|}
\hline Year & $\begin{array}{c}\text { Per } \\
\text { capita } \\
\text { (KWh) }\end{array}$ & $\begin{array}{l}\text { Growth } \\
\text { Rate } \\
\text { (\%) }\end{array}$ & Year & $\begin{array}{c}\text { Per } \\
\text { capita } \\
\text { (KWh) }\end{array}$ & $\begin{array}{c}\text { Growth } \\
\text { rate } \\
\text { (\%) }\end{array}$ & Year & $\begin{array}{c}\text { Per } \\
\text { Capita } \\
\text { (KWh) }\end{array}$ & $\begin{array}{c}\text { Growth } \\
\text { Rate } \\
\text { (\%) }\end{array}$ & Year & $\begin{array}{c}\text { Per } \\
\text { Capita } \\
\text { (KWh) }\end{array}$ & $\begin{array}{c}\text { Growth } \\
\text { rate } \\
\text { (\%) }\end{array}$ \\
\hline 1975 & 318.3 & 11.1 & 1984 & 609.9 & 7.7 & 1993 & 1010.9 & 9.5 & 2002 & 1584.8 & 6.5 \\
\hline 1976 & 348.1 & 9.4 & 1985 & 644.5 & 5.7 & 1994 & 1090.8 & 7.9 & 2003 & 1702.8 & 7.4 \\
\hline 1977 & 376.2 & 8.1 & 1986 & 659.7 & 2.4 & 1995 & 1112.6 & 2.0 & 2004 & 1821.1 & 6.9 \\
\hline 1978 & 392.1 & 4.2 & 1987 & 685.7 & 3.9 & 1996 & 1160.1 & 4.3 & 2005 & 1915.2 & 5.2 \\
\hline 1979 & 418.9 & 6.9 & 1988 & 696.4 & 1.6 & 1997 & 1203.9 & 3.8 & 2006 & 2051.2 & 7.1 \\
\hline 1980 & 425.4 & 1.5 & 1989 & 751.2 & 7.9 & 1998 & 1255.8 & 4.3 & 2007 & 2136.8 & 4.2 \\
\hline 1981 & 442.3 & 4.0 & 1990 & 827.7 & 10.2 & 1999 & 1349.4 & 7.5 & 2008 & 2224.0 & 4.1 \\
\hline 1982 & 491.9 & 11.2 & 1991 & 880.7 & 6.4 & 2000 & 1419.4 & 5.2 & 2009 & 2307.0 & 3.7 \\
\hline 1983 & 566.0 & 15.1 & 1992 & 923.2 & 4.8 & 2001 & 1488.0 & 4.8 & 2010 & 2525.0 & 9.4 \\
\hline
\end{tabular}

Source: CBI (2010); TAVANIR (2010); author's calculations.

${ }^{21} \mathrm{CBI}$ and IIES both refer to the Central Bank of Iran and the Institute for International Energy Studies. 
Table 2: Studies on Residential Electricity Demand Modelling

\begin{tabular}{|c|c|c|c|}
\hline $\begin{array}{c}\text { Author } \\
\text { Country } \\
\text { Sample }\end{array}$ & $\frac{\text { Methodology }}{\text { Unit root test }}$ & $\begin{array}{l}\text { Variables \& (Long-run elasticity/Short-run } \\
\text { elasticity) }\end{array}$ & Conclusion \\
\hline $\begin{array}{c}\text { Flaig (1990) } \\
\text { Germany } \\
1964-1983 \text { (22 years) }\end{array}$ & $\frac{\text { Wold (1974) }}{\text { No unit root test }}$ & $\begin{array}{l}\text {-Real electricity expenditure }(0.14 / 0) \\
\text {-Electricity price index }(-0.25 /-0.15) \\
\text {-Real price of electric appliances }(-0.43 / 0) \\
\text {-Real price of services of laundries }(0.63 / 0.37) \\
\text {-Real price of fuel oil }(0.11 / 0.07)\end{array}$ & $\begin{array}{l}\text { The relationship between electricity demand and capital stock } \\
\text { plays a significant role in the estimated model. Higher prices } \\
\text { of market services lead to a growing rate of household } \\
\text { production and higher income and lower prices of durables } \\
\text { cause a substitution of energy for labour. }\end{array}$ \\
\hline $\begin{array}{l}\text { Silk \& Joutz (1997) } \\
\text { US } \\
1949-1993 \text { (45years) }\end{array}$ & $\frac{-\mathrm{JJ}^{22}}{-\mathrm{ADF}}$ & $\begin{array}{l}\text {-Real disposable income }(0.52 \text { / 0.39) } \\
\text {-Real electricity price }(-0.48 /-0.63) \\
\text {-Real price of fuel oil }(0.06 / 0.05) \\
\text {-cdd }(0.26 / 0.16) \\
\text {-hdd }(0.16 / 0.12) \\
\text {-Dummy for } 1963(-0.06 / \mathrm{N})^{23}\end{array}$ & $\begin{array}{l}\text {-A break was found in electricity demand in } 1963 \text { which was } \\
\text { important for energy policy making associated with policy } \\
\text { changes of the } 1960 \text { 's. } \\
\text {-Adjustment speed to long-run mean: }-0.37\end{array}$ \\
\hline$\frac{\text { Beenstock et al. (1999) }}{\text { Israel }}$ & $\begin{array}{l}\text {-Johansen (1988) } \\
-\mathrm{EG}^{24} \\
-\mathrm{DRM}^{25} \\
\text { Dickey et al. (1984) }\end{array}$ & $\begin{array}{l}\text {-Real consumer spending }(1.00 \text { to } 1.09 / \mathrm{N}) \\
\text {-Relative price of electricity } \\
(-0.21 \text { to }-0.58 / \mathrm{N}) \\
\text {-hdd and cdd }(0 / \mathrm{N}) \\
\text {-Seasonal dummies }(0 / \mathrm{N})\end{array}$ & $\begin{array}{l}\text { A cointegrating relationship was not detected. The elasticities } \\
\text { of the Johansen and DRM approaches are similar. }\end{array}$ \\
\hline $\begin{array}{c}\text { Filippini (1999) } \\
\text { Switzerland } \\
1987-1990 \\
\text { Cross sectional data } \\
\text { (40 cities) }\end{array}$ & $\begin{array}{l}\text {-OLS } \\
\text {-Error component } \\
\text { model (Balestra \& } \\
\text { Nerlove, 1966) } \\
\text { No unit root test }\end{array}$ & $\begin{array}{l}\text {-Price index }(-0.25 \text { to }-0.60 / \mathrm{N}) \\
\text {-Real household income }(0.33 \text { to } 0.39 / \mathrm{N}) \\
\text {-Number of households }(0.90 \text { to } 0.92 / \mathrm{N}) \\
\text {-Size of household }(1.08 \text { to } 1.53 / \mathrm{N}) \\
\text {-HDD }(0.06 \text { to } 0.30 / \mathrm{N})\end{array}$ & $\begin{array}{l}\text { Lower elasticities compared to previous studies. There was } \\
\text { little room to persuade consumers to decrease electricity } \\
\text { demand using a price rise. }\end{array}$ \\
\hline
\end{tabular}

\footnotetext{
22 Johansen and Juselius (1990)

${ }^{23} \mathrm{~N}$ denotes that the elasticity has not been estimated by the study.

24 (Engle and Granger, 1987).

${ }^{25}$ Dynamic Regression Model.
} 
Table 2: Continued

\begin{tabular}{|c|c|c|c|}
\hline $\begin{array}{l}\text { Author } \\
\text { Country } \\
\text { Sample }\end{array}$ & $\frac{\text { Methodology }}{\text { Unit root test }}$ & $\begin{array}{l}\text { Variables \& (Long-run elasticity/Short-run } \\
\text { elasticity) }\end{array}$ & Conclusion \\
\hline$\frac{\frac{\text { Askari (2002) }}{\text { Iran }}}{1995-1999 \text { (Panel data) }}$ & $\frac{- \text { GLS }^{26}}{\text { No unit root test }}$ & $\begin{array}{l}\text {-Residential electricity consumption } \\
\text {-Real residential electricity price }(-1.36 \text { / }-0.97) \\
\text {-Squared real price of residential electricity }(0.44 \text { / } \\
0.32) \\
\text {-Real price of substitute fuel }(0.48 \text { / } 0.34) \\
\text {-Real income }(0.16 \text { / } 0.11) \\
\text {-Lagged residential electricity demand }(0.41 \text { / } \\
0.29)\end{array}$ & $\begin{array}{l}\text { Due to elastic price, pricing policies could be appropriate tools } \\
\text { for controlling residential electricity demand. The rich and } \\
\text { climatically warm provinces have higher price elasticities than } \\
\text { other provinces. }\end{array}$ \\
\hline $\begin{array}{l}\frac{\text { Amini Fard \& Estedlal (2003) }}{\text { Iran }} \\
1967-2000 \text { (33 years }\end{array}$ & $\begin{array}{l}-\mathrm{JJ} \\
-\mathrm{ECM} \\
-\mathrm{ADF}\end{array}$ & $\begin{array}{l}\text {-Electricity consumption, I(1) } \\
\text {-Real electricity price, I(1), }(-0.59 \text { / 0) } \\
\text {-Real liquid-gas price, I(1), }(0.46 \text { / 0) } \\
\text {-Real disposable income, I(1), }(0.24 \text { / 0) } \\
\text {-Number of consumers, I(1), }(1.10 \text { / 0.64) }\end{array}$ & $\begin{array}{l}\text { The impact of an income shock on electricity demand is bigger } \\
\text { than the effect of an electricity-price shock. The reason for the } \\
\text { low price elasticity is the small proportion of an electricity bill } \\
\text { in household expenditure. Low income elasticity shows that } \\
\text { electricity is a necessary good for households. } \\
\text {-Adjustment speed to long-run mean:-0.5 }\end{array}$ \\
\hline $\begin{array}{c}\text { Holtedahl \& Joutz }(2004) \\
\text { Taiwan } \\
1956-1995 \text { (40 years) }\end{array}$ & $\begin{array}{l}\text {-Hendry \& } \\
\text { Juselius(2000; 2001) } \\
\text {-ADF }\end{array}$ & $\begin{array}{l}\text {-Real per capita disposable income }(1.04 \text { / 0.23) } \\
\text {-Real electricity demand }(-0.15 \text { / -0.15) } \\
\text {-Urbanization }(3.91 / 1.61) \\
\text {-CDD }(0 / 0.03)\end{array}$ & $\begin{array}{l}\text { The positive coefficient on the urbanization rate a sign of } \\
\text { Taiwan Power industry requirement to serve clients, but also a } \\
\text { sign of a tendency of urban consumers to use more electricity } \\
\text { compared to rural end users. } \\
\text { - Adjustment speed to long-run equilibrium: }-0.11\end{array}$ \\
\hline $\begin{array}{c}\text { Kamerschen \& Porter }(2004) \\
\text { US } \\
1973-1998 \text { (26 years })\end{array}$ & $\begin{array}{l}\text {-SEM (3SLS) } \\
\text {-The partial adjustment } \\
\text { Model } \\
\text { No unit root test }\end{array}$ & $\begin{array}{l}\text {-Real income ( } 0.65 \text { to } 0.69 \text { / } \mathrm{N}) \\
\text {-Real marginal electricity price }(-0.85 \text { to }-0.94 / \mathrm{N}) \\
\text {-Real price of natural gas }(0.33 \text { to } 0.34 \text { / N) }\end{array}$ & $\begin{array}{l}\text { Residential end users are more responsive to price changes } \\
\text { compared to industrial customers. Cold weather affects } \\
\text { residential electricity demand more than hot weather. Iignoring } \\
\text { endogeneity of prices leads to spurious results. }\end{array}$ \\
\hline $\begin{array}{c}\frac{\text { Narayan \& Smyth }(2005)}{\text { Australia }} \\
1969-2000 \text { (32 years) }\end{array}$ & $\begin{array}{l}\text {-ARDL } \\
\text {-ECM } \\
\text {-ADF }\end{array}$ & $\begin{array}{l}\text { Model 1: } \\
\text {-Real per capita income }(0.32 / 0) \\
\text {-Real price of electricity }(-0.54 /-0.26) \\
\text {-Real price of gas }(0 / 0) \\
\text {-Temperature }(1.69 / 0)\end{array}$ & $\begin{array}{l}\text { Changes in carbon emissions due to the imposition of a carbon } \\
\text { tax in Australia are slower than what Akmal and Stern (2001) } \\
\text { found. Reduction of carbon emissions will be minor in the } \\
\text { short-run in response to policy changes for carbon emissions } \\
\text { reduction. }\end{array}$ \\
\hline
\end{tabular}

\footnotetext{
${ }^{26}$ Generalised Least Squares.

${ }^{27}$ Simultaneous equations method three stage least squares.
} 
Table 2: Continued

\begin{tabular}{|c|c|c|c|}
\hline $\begin{array}{l}\text { Author } \\
\text { Country } \\
\text { Sample }\end{array}$ & $\frac{\text { Methodology }}{\text { Unit root test }}$ & $\begin{array}{l}\text { Variables \& (Long-run elasticity/Short-run } \\
\text { elasticity) }\end{array}$ & Conclusion \\
\hline & & $\begin{array}{l}\text { Model 2: } \\
\text {-Real per capita income }(0.41 / 0) \\
\text {-Relative price (electricity/gas) }(-0.47 /-0.27)\end{array}$ & -Adjustment speed to long-run mean: -0.10 to -0.37 \\
\hline $\begin{array}{c}\begin{array}{c}\text { Narayan et al. } \\
(2007)\end{array} \\
\text { G7 }\end{array}$ & \multirow{2}{*}{$\begin{array}{l}\text {-Pedroni (2004) } \\
\text {-OLS } \\
\text {-Panel DOLS } \\
\text { (Breitung, 2000) } \\
- \text { ADF } \\
- \text { PP }^{29}\end{array}$} & $\begin{array}{l}\text { Model 1: } \\
\text {-Real per capita income }(0.26 \text { to } 0.31 \text { / } 0) \\
\text {-Real price of electricity } \\
\text { (-1.45 to }-1.56 /-0.11) \\
\text {-Real price of gas }(1.77 / 0) \\
\end{array}$ & \multirow{2}{*}{$\begin{array}{l}\text { There is room to use pricing policies in the G7 countries to } \\
\text { curb residential electricity demand and carbon emissions, in } \\
\text { the long run, through the imposition of a carbon tax. } \\
\text {-Adjustment speed to long-run equilibrium: }-0.01\end{array}$} \\
\hline $\begin{array}{l}\text { 1978-2003 (26 years) } \\
\text { Panel data }\end{array}$ & & $\begin{array}{l}\text { Model 2: } \\
\text {-Real per capita income }(0.35 \text { to o.37 / 0) } \\
\text {-Relative price ( electricity/gas) } \\
\text { (-6.87 to }-7.41 / 0)\end{array}$ & \\
\hline $\begin{array}{c}\begin{array}{c}\text { Zachariadis \& Pashourtidou } \\
\text { (2007) }\end{array} \\
\text { Cyprus } \\
1960-2004 \text { ( } 45 \text { years })\end{array}$ & $\begin{array}{l}- \text { Johansen } \\
(1988 ; 1991) \\
\text {-ECM } \\
- \text { ADF } \\
\text {-PP }\end{array}$ & $\begin{array}{l}\text {-Real private consumption expenditure } \\
(1.18 \text { / 0) } \\
\text {-Real price of residential electricity }(-0.43 \text { / 0) } \\
\text {-Total degree-day }(0 \text { / 0.02) }\end{array}$ & $\begin{array}{l}\text { The speed of commercial electricity demand to revert to long- } \\
\text { run equilibrium after a one-time shock is quicker than the } \\
\text { residential sector. } \\
\text {-Adjustment speed to long-run equilibrium: }-0.16 \text { to }-0.23\end{array}$ \\
\hline $\begin{array}{c}\text { Atakhanova \& } \\
\text { Howie (2007) } \\
\text { Kazakhstan } \\
1994-2003 \\
\text { Cross sectional data } \\
\text { (14 regions) }\end{array}$ & $\frac{-\mathrm{GMM}^{30}}{\text { No unit root test }}$ & $\begin{array}{l}\text {-Real per capita consumer expenditure } \\
\text { ( } 0.12 \text { to } 0.59 \text { / N) } \\
\text {-Real electricity price (-0.22 to }-1.10 \text { / N) }\end{array}$ & $\begin{array}{l}\text { Energy policy initiatives are necessary to guarantee } \\
\text { affordability by lower income residential consumers of } \\
\text { electricity. Electricity consumption may rise at either } 3 \% \text { or } \\
5 \% \text { per year in the future. If real electricity prices rise toward } \\
\text { their long-run cost-recovery levels, the planned supply growth } \\
\text { can cover increasing electricity consumption. }\end{array}$ \\
\hline
\end{tabular}

\footnotetext{
${ }^{28}$ Dynamic Ordinary least squares.

${ }^{29}$ (Phillips and Perron (1988).

${ }^{30}$ Generalized method of movement (Arellano \& Bond, 1991).
} 
Table 2: Continued

\begin{tabular}{|c|c|c|c|}
\hline $\begin{array}{l}\text { Author } \\
\text { Country } \\
\text { Sample }\end{array}$ & $\frac{\text { Methodology }}{\text { Unit root test }}$ & $\begin{array}{l}\text { Variables \& (Long-run elasticity/Short-run } \\
\text { elasticity) }\end{array}$ & Conclusion \\
\hline $\begin{array}{c}\begin{array}{c}\text { Dergiades \& } \\
\text { Tsoulfidis (2008) }\end{array} \\
\text { US } \\
1965-2006 \text { (42 years) }\end{array}$ & $\begin{array}{l}-\mathrm{ARDL} \\
-\mathrm{ECM} \\
-\mathrm{ADF}\end{array}$ & $\begin{array}{l}\text {-Real per capita income }(0.27 / 0.10) \\
\text {-Real price of electricity }(-1.60 /-0.38) \\
\text {-Real price of oil }(0.20 / 0) \\
\text {-Weather condition }(0.73 / 0.26) \\
\text {-Per capita occupied housing stock }(1.50 / 0)\end{array}$ & $\begin{array}{l}\text { The results support the existence of a stable long-run } \\
\text { relationship. The size and sign of the short-run and long-run } \\
\text { elasticities are comparable to other similar studies. } \\
\text {-Adjustment speed to long-run equilibrium: }-0.36\end{array}$ \\
\hline $\begin{array}{c}\text { Nakajima (2010) } \\
\text { Japan } \\
\text { 1975-2005 (31 years) } \\
\text { Cross sectional data } \\
\text { (46 regions) }\end{array}$ & $\begin{array}{l}\text {-Pedroni (1999) } \\
\text {-Maddala and Shaowen } \\
\text { (1999) } \\
\text {-Group-mean DOLS } \\
\text {-Levin et al. (2002) } \\
\text {-Im et al. (2003) }\end{array}$ & $\begin{array}{l}\text {-Real disposable income per household } \\
(0.60 \text { to } 0.65 \text { / N) } \\
\text {-Real price of electricity (-1.20 to } 1.13 \text { / N) }\end{array}$ & $\begin{array}{l}\text { Contrary to previous studies on Japanese electricity demand, } \\
\text { prices are elastic. Higher incomes do not result in a substantial } \\
\text { rise in electricity demand because most consumers already } \\
\text { have many household electric appliances. }\end{array}$ \\
\hline
\end{tabular}

\footnotetext{
${ }^{31}$ Dynamic Ordinary least squares.
} 
Table 3: Unit Root Test Results

a) $\mathrm{ADF}$ test $\quad \Delta y_{t}=\alpha y_{t-1}+\sum_{i=1}^{k} \beta_{i} \Delta y_{t-i}+x_{t}^{\prime} \gamma+u_{t}$

\begin{tabular}{|c|c|c|c|c|}
\hline \multirow{2}{*}{ Variables } & \multicolumn{3}{|c|}{ Level } & \multirow{2}{*}{ Results } \\
\hline & $\mathrm{k}$ & $\alpha$ & Exogenous & \\
\hline $\mathrm{Cr}$ & 0 & -1.65 & C\&T & $\mathrm{I}(1)$ \\
\hline epr & 0 & -0.93 & C\&T & $\mathrm{I}(1)$ \\
\hline nv & 2 & -3.11 & C\&T & $\mathrm{I}(1)$ \\
\hline gp & 0 & -1.92 & C\&T & $\mathrm{I}(1)$ \\
\hline hco & 4 & -2.50 & C\&T & $\mathrm{I}(1)$ \\
\hline $\mathrm{cd}$ & 0 & $-3.62 *$ & $\mathrm{C}$ & $\mathrm{I}(0)$ \\
\hline
\end{tabular}

Note: $*, * *, * * *$ denote significance at the $1 \%, 5 \%$, and $10 \%$ level. $k$ is number of optimal lagged length and the maximum lag is four. $C$ denotes intercept and $T$ denotes trend.

b) LS test with (level) $\quad \Delta y_{t}=\delta^{\prime} \Delta Z_{t}+\alpha \tilde{y}_{t-1}+\sum \Delta \tilde{y}_{t-i}+u_{t}$

\begin{tabular}{|c|c|c|c|c|c|c|c|c|c|}
\hline Variable & Model & $\mathrm{k}$ & $\alpha$ & $\begin{array}{l}\text { Tb1 } \\
\text { Tb2 }\end{array}$ & $\mathrm{D}_{1 \mathrm{t}}$ & $\mathrm{DT}_{1 \mathrm{t}}$ & $\mathrm{D}_{2 \mathrm{t}}$ & $\mathrm{DT}_{2 \mathrm{t}}$ & Results \\
\hline $\mathrm{Cr}$ & $\mathrm{CC}$ & 4 & $\begin{array}{l}-1.03 * \\
(-5.99)\end{array}$ & $\begin{array}{l}1980 \\
1990\end{array}$ & $\begin{array}{l}-0.156 \\
(-4.48)\end{array}$ & $\begin{array}{c}0.05 \\
(2.04)\end{array}$ & $\begin{array}{c}0.10 \\
(2.99)\end{array}$ & $\begin{array}{c}-0.18 \\
(-7.72)\end{array}$ & $\begin{array}{l}\mathrm{I}(0) \text { with } \\
\text { two breaks }\end{array}$ \\
\hline epr & $\mathrm{CC}$ & 2 & $\begin{array}{c}-0.98 \\
(-4.72) \\
\end{array}$ & $\begin{array}{l}1978 \\
1986 \\
\end{array}$ & $\begin{array}{c}-0.33 \\
(-2.00) \\
\end{array}$ & $\begin{array}{c}0.30 \\
(2.80) \\
\end{array}$ & $\begin{array}{c}0.27 \\
(1.60)\end{array}$ & $\begin{array}{c}-0.29 \\
(-2.68)\end{array}$ & $\begin{array}{c}\text { I(1) with } \\
\text { two breaks }\end{array}$ \\
\hline nv & $\mathrm{CC}$ & 4 & $\begin{array}{l}-0.31^{*} \\
(-7.36)\end{array}$ & $\begin{array}{l}1977 \\
1993 \\
\end{array}$ & $\begin{array}{c}-0.13 \\
(-3.71)\end{array}$ & $\begin{array}{c}-0.08 \\
(-2.78)\end{array}$ & $\begin{array}{c}0.09 \\
(2.81) \\
\end{array}$ & $\begin{array}{c}-0.15 \\
(-10.39)\end{array}$ & $\begin{array}{l}\mathrm{I}(0) \text { with } \\
\text { two breaks }\end{array}$ \\
\hline gp & $\mathrm{CC}$ & 4 & $\begin{array}{l}-1.25^{*} \\
(-6.18) \\
\end{array}$ & $\begin{array}{l}1980 \\
1990 \\
\end{array}$ & $\begin{array}{c}-0.73 \\
(-3.37) \\
\end{array}$ & $\begin{array}{c}0.47 \\
(4.43) \\
\end{array}$ & $\begin{array}{c}0.94 \\
(4.21) \\
\end{array}$ & $\begin{array}{c}-0.97 \\
(-5.38) \\
\end{array}$ & $\begin{array}{c}\mathrm{I}(0) \text { with } \\
\text { two breaks }\end{array}$ \\
\hline hco & $\mathrm{CC}$ & 4 & $\begin{array}{l}-0.74 * * \\
(-5.67)\end{array}$ & $\begin{array}{l}1984 \\
1994 \\
\end{array}$ & $\begin{array}{c}0.10 \\
(1.95)\end{array}$ & $\begin{array}{c}-0.20 \\
(-6.55)\end{array}$ & $\begin{array}{c}-0.09 \\
(-1.86)\end{array}$ & $\begin{array}{c}0.06 \\
(3.27)\end{array}$ & $\begin{array}{l}\mathrm{I}(0) \text { with } \\
\text { two breaks }\end{array}$ \\
\hline $\mathrm{cd}$ & $\mathrm{CC}$ & 0 & $\begin{array}{l}-1.05^{*} \\
(-5.98) \\
\end{array}$ & $\begin{array}{l}1990 \\
1994 \\
\end{array}$ & $\begin{array}{c}0.05 \\
(0.50) \\
\end{array}$ & $\begin{array}{c}-0.07 \\
(-1.18) \\
\end{array}$ & $\begin{array}{c}-0.08 \\
(-0.84) \\
\end{array}$ & $\begin{array}{c}0.24 \\
(3.47) \\
\end{array}$ & $\begin{array}{c}\mathrm{I}(0) \text { with } \\
\text { two breaks }\end{array}$ \\
\hline
\end{tabular}

Note: *,**,*** denote significance at the $1 \%, 5 \%$, and $10 \%$ level. Critical values are tabulated in Lee and Strazicich (2001, Table 1). Critical values at the 1 and 5, and $10 \%$ for AA model are -4.545 , -3.84 , and -3.504 and for CC model are -5.823 , -5.286 , and -4.989 . For models with one break the critical values tabulated in Lee and Strazicich (2003, Table 2). The critical values for model C depending on the location of the break change from -5.05 to -5.11 , -4.45 to -4.51 , and -4.17 to -4.20 and for Model A are $-4.239,-3.566$, and -3.211 , respectively. TB1 and TB2 are the break dates, $k$ is number of optimal lagged length and maximum lag is four. Numbers in parentheses are the $t$ statistics for the estimated coefficients. 
c) NP test with two breaks (level)

\begin{tabular}{|c|c|c|c|c|c|c|c|c|c|c|}
\hline \multirow[b]{2}{*}{ Series } & \multicolumn{5}{|c|}{ M2 } & \multicolumn{4}{|c|}{ M1 } & \multirow[b]{2}{*}{ Results } \\
\hline & $\mathrm{k}$ & $\begin{array}{l}\text { Test } \\
\text { stat. } \\
\end{array}$ & $\begin{array}{l}\text { TB1 } \\
\text { TB2 } \\
\end{array}$ & $\kappa_{1}$ & $\kappa_{2}$ & $\begin{array}{l}\text { Test } \\
\text { stat. }\end{array}$ & $\begin{array}{l}\text { TB1 } \\
\text { TB2 } \\
\end{array}$ & $\theta_{1}$ & $\theta_{2}$ & \\
\hline $\mathrm{cr}$ & 0 & $\begin{array}{l}-0.33 * \\
(-7.60) \\
\end{array}$ & $\begin{array}{l}1974 \\
1980 \\
\end{array}$ & $\begin{array}{c}0.02 \\
(3.43) \\
\end{array}$ & $\begin{array}{c}-0.01 \\
(-3.00) \\
\end{array}$ & 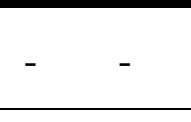 & 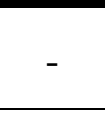 & & & $\begin{array}{c}\mathrm{I}(0) \text { with two } \\
\text { breaks }\end{array}$ \\
\hline epr & 2 & $\begin{array}{c}-1.00 \\
(-3.85)\end{array}$ & $\begin{array}{l}1988 \\
1995\end{array}$ & $\begin{array}{c}-0.08 \\
(-1.66)\end{array}$ & $\begin{array}{c}0.06 \\
(0.93)\end{array}$ & $0 \begin{array}{c}-0.69 \\
(-2.86)\end{array}$ & $\begin{array}{l}1982 \\
1998 \\
\end{array}$ & $\begin{array}{c}-0.10 \\
(-2.09)\end{array}$ & $\begin{array}{c}0.09 \\
(1.65)\end{array}$ & $\begin{array}{l}\text { I(1) with two } \\
\text { breaks }\end{array}$ \\
\hline nv & 1 & $\begin{array}{l}-0.13^{*} \\
(-6.47) \\
\end{array}$ & $\begin{array}{l}1974 \\
\mathbf{1 9 7 7} \\
\end{array}$ & $\begin{array}{c}-0.02 \\
(-3.27) \\
\end{array}$ & $\begin{array}{c}-0.03 \\
(-4.79) \\
\end{array}$ & - & - & 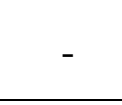 & - & $\begin{array}{l}\mathrm{I}(0) \text { with two } \\
\text { breaks }\end{array}$ \\
\hline gp & 3 & $\begin{array}{c}-1.15 \\
(-4.24)\end{array}$ & $\begin{array}{l}1981 \\
1996\end{array}$ & $\begin{array}{c}0.14 \\
(2.56)\end{array}$ & $\begin{array}{c}0.01 \\
(1.28)\end{array}$ & $0 \begin{array}{c}-0.27 \\
(-1.41)\end{array}$ & $\begin{array}{l}1981 \\
1996\end{array}$ & $\begin{array}{c}0.25 \\
(4.28)\end{array}$ & $\begin{array}{c}0.12 \\
(2.10)\end{array}$ & $\begin{array}{l}\text { I(1) with two } \\
\text { breaks }\end{array}$ \\
\hline hco & 0 & $\begin{array}{c}-0.10 \\
(-1.20)\end{array}$ & $\begin{array}{l}1975 \\
1985\end{array}$ & $\begin{array}{c}-0.03 \\
(-5.81)\end{array}$ & $\begin{array}{c}-0.01 \\
(-3.55)\end{array}$ & $-\quad-$ & - & - & - & $\begin{array}{l}\text { I(1) with two } \\
\text { breaks }\end{array}$ \\
\hline $\mathrm{cd}$ & 0 & $\begin{array}{l}-0.81 * \\
(-6.22)\end{array}$ & $\begin{array}{l}1978 \\
1991 \\
\end{array}$ & $\begin{array}{c}-0.04 \\
(-4.48)\end{array}$ & $\begin{array}{c}0.03 \\
(-3.31)\end{array}$ & - & - & - & - & $\begin{array}{l}\mathrm{I}(0) \text { with two } \\
\text { breaks }\end{array}$ \\
\hline
\end{tabular}

Note: *,**,*** denote significance at the $1 \%, 5 \%$, and $10 \%$ level. Critical values are tabulated in Narayan and Popp (2010, Table 3). Critical values at the 1 and 5, and 10\% for M1 model are -5.259 , -4.514 , and -4.143 and for M2 model are $-5.949,-5.181$, and -4.789 . TB1 and TB2 are the break dates, $k$ is number of optimal lagged length and maximum lag is four. Numbers in parentheses are the $t$-statistics for the estimated coefficients.

Table 4: Major Determinant of Long-Run Residential Electricity Demand, 1967-2009

\begin{tabular}{ccc}
\hline Regressors & Coefficient & T-Ratio[Prob] \\
\hline epr & -0.11 & $-0.92[0.37]$ \\
hco & 0.58 & $4.53[0.00]$ \\
nv & 0.36 & $5.69[0.00]$ \\
cd & 1.04 & $3.31[0.00]$ \\
gp & -0.10 & $-1.12[0.27]$ \\
c & -10.08 & $-3.37[0.00]$ \\
\hline $\bar{R}^{2}: 0.99$ & $D W: 1.91$ & F-statistic: 3.92 \\
\hline \multirow{2}{*}{ Diagnostic tests } & LM version & F version \\
& Test statistic [Prob] & Test statistic [Prob] \\
\hline Serial Correlation & $0.01[0.94]$ & $0.00[0.95]$ \\
Functional Form & $0.36[0.55]$ & $0.23[0.63]$ \\
Normality & $3.44[0.18]$ & Not applicable \\
Heteroscedasticity & $2.66[0.10]$ & $2.71[0.11]$ \\
\hline
\end{tabular}


Table 5: Major Determinants of Short-Run Residential Electricity Demand, 1967-2009

\begin{tabular}{ccc}
\hline Regressors & Coefficient & T-Ratio[Prob] \\
\hline c & 0.01 & $0.51[0.61]$ \\
dhco & 0.04 & $0.43[0.67]$ \\
dhco(-1) & 0.19 & $1.90[0.07]$ \\
depr & -0.03 & $-0.66[0.52]$ \\
dcd & 0.14 & $3.21[0.00]$ \\
ecm(-1) & -0.21 & $-8.30[0.00]$ \\
\hline $\bar{R}^{2}:$ 0.73 & $D W: 2.48$ & --- \\
\hline Diagnostic tests $^{2}$ & LM version & F version \\
\hline Serial Correlation & Test statistic [Prob] & Test statistic [Prob] \\
Functional Form & $3.10[0.08]$ & $2.78[0.11]$ \\
Normality & $0.03[0.87]$ & $0.02[0.88]$ \\
Heteroscedasticity & $5.75[0.06]$ & Not applicable \\
\hline
\end{tabular}

Note: $d$ denotes the first difference value of the variables.

Figure 2: Stability Test of Estimated models of Residential electricity Demand

CUSUM Test of the Long-Run Demand

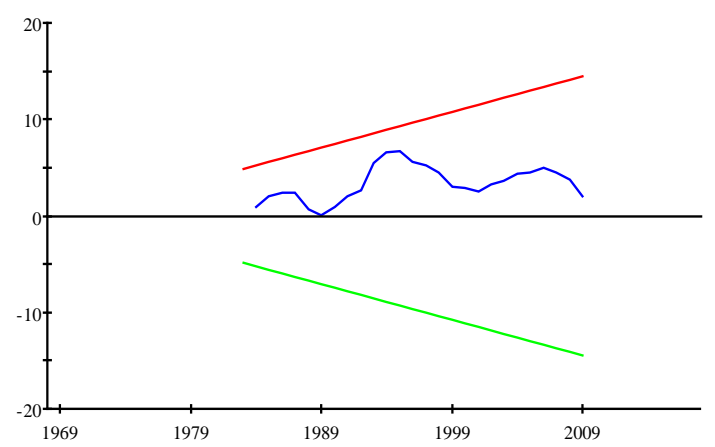

CUSUM Test of the Short-Run Demand

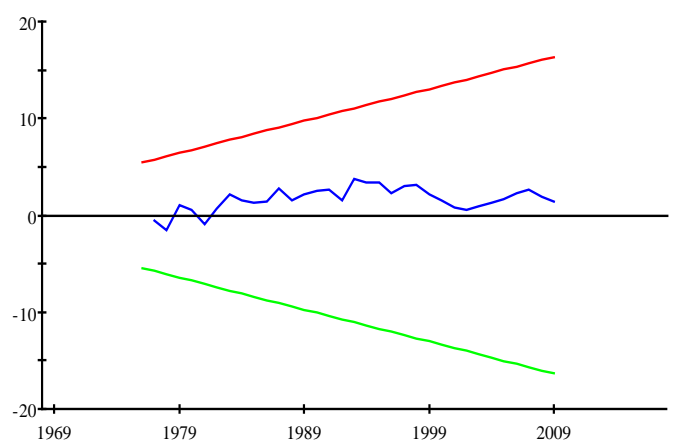

CUSUMSQ Test of the Long-Run Demand

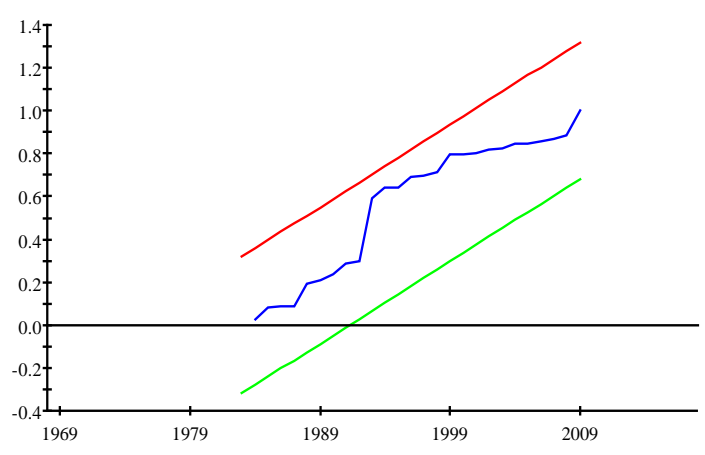

CUSUMSQ Test of the Short-Run Demand

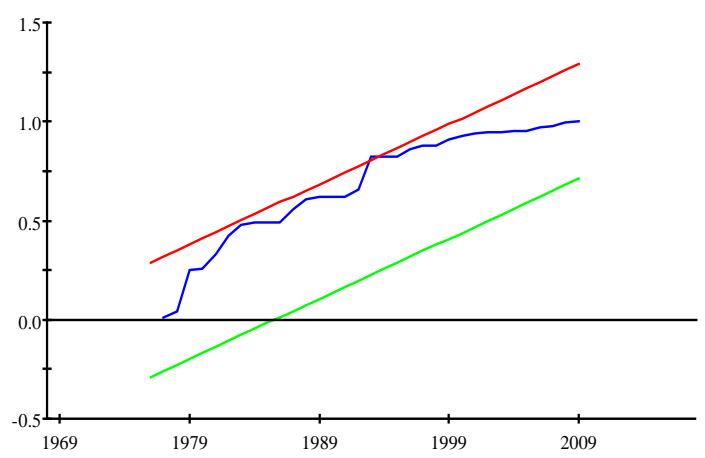


Table 6: Quandt-Andrews unknown breakpoint test

Null Hypothesis: No breakpoints within trimmed data

Varying regressors: C LOG(EPR) LOG(HCO) LOG(NV) LOG(CD) LOG(GPR)

Equation Sample: 19692009

Test Sample: 19762002

Number of breaks compared: 27

\begin{tabular}{lll}
\hline Statistic & Value & Prob. \\
\hline Maximum LR F-statistic (1980) & 4.854316 & 0.9908 \\
Maximum Wald F-statistic (1980) & 4.854316 & 0.9908 \\
\hline Exp LR F-statistic & 0.952181 & 0.9997 \\
Exp Wald F-statistic & 0.952181 & 0.9997 \\
\hline Ave LR F-statistic & 1.459397 & 0.9998 \\
Ave Wald F-statistic & 1.459397 & 0.9998 \\
\hline
\end{tabular}


Dependent variable is $\mathrm{cr}$

List of the variables added to the regression (residual of the independent variables):

r_epr r_hco r_gp r_nv

41 observations used for estimation from 1969 to 2009

\begin{tabular}{|c|c|c|c|}
\hline Regressor & Coefficient & Standard Error & T-Ratio[Prob] \\
\hline C & -.40346 & .43444 & $-.92871[.361]$ \\
\hline $\operatorname{cr}(-1)$ & .78094 & .16406 & $4.7600[.000]$ \\
\hline epr & .069368 & .13844 & $.50108[.620]$ \\
\hline epr(-1) & -.081276 & .12236 & $-.66424[.512]$ \\
\hline hco & .44480 & .36816 & $1.2082[.237]$ \\
\hline hсo(-1) & -.31437 & .29303 & $-1.0728[.293]$ \\
\hline gp & .070507 & .072323 & $.97489[.338]$ \\
\hline gp(-1) & -.047245 & .038662 & $-1.2220[.232]$ \\
\hline nv & -.026067 & .45453 & $-.057348[.955]$ \\
\hline$n v(-1)$ & .12898 & .50332 & $.25625[.800]$ \\
\hline r_epr & -.072600 & .15156 & $-.47903[.636]$ \\
\hline r_hco & -.49017 & .39360 & $-1.2453[.224]$ \\
\hline r_gp & -.053803 & .079353 & $-.67802[.504]$ \\
\hline r_nv & .18697 & .47932 & $.39007[.700]$ \\
\hline \multicolumn{4}{|c|}{ Joint test of zero restrictions on the coefficients of additional variables: } \\
\hline \multicolumn{2}{|c|}{ Lagrange Multiplier Statistic } & $\mathrm{CHSQ}(4)=7.9538[.093]$ & \\
\hline \multicolumn{2}{|c|}{ Likelihood Ratio Statistic } & $\operatorname{CHSQ}(4)=8.8423[.065]$ & \\
\hline \multicolumn{2}{|l|}{ F Statistic } & $F(4,27)=1.6246[.197]$ & \\
\hline
\end{tabular}


Figure3: Forecast Assumptions of Residential Electricity Demand

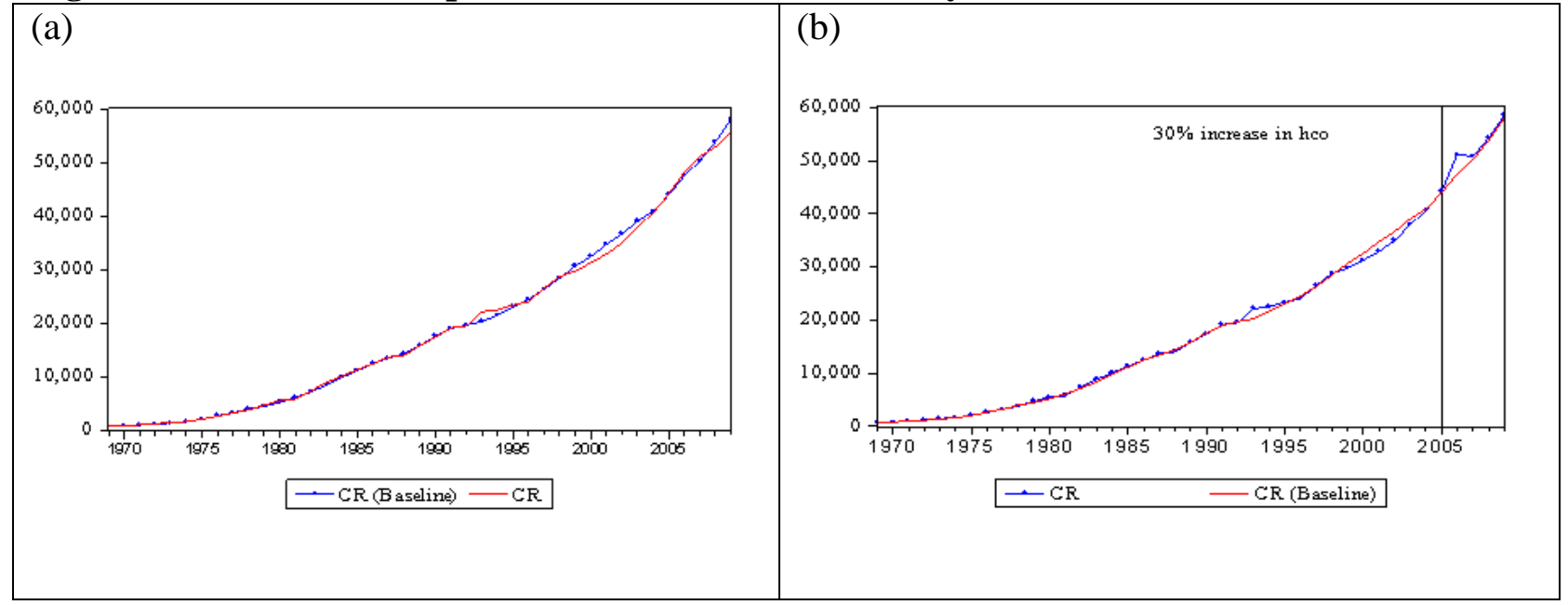

Figure 4: Forecast Assumptions of Residential Electricity Demand

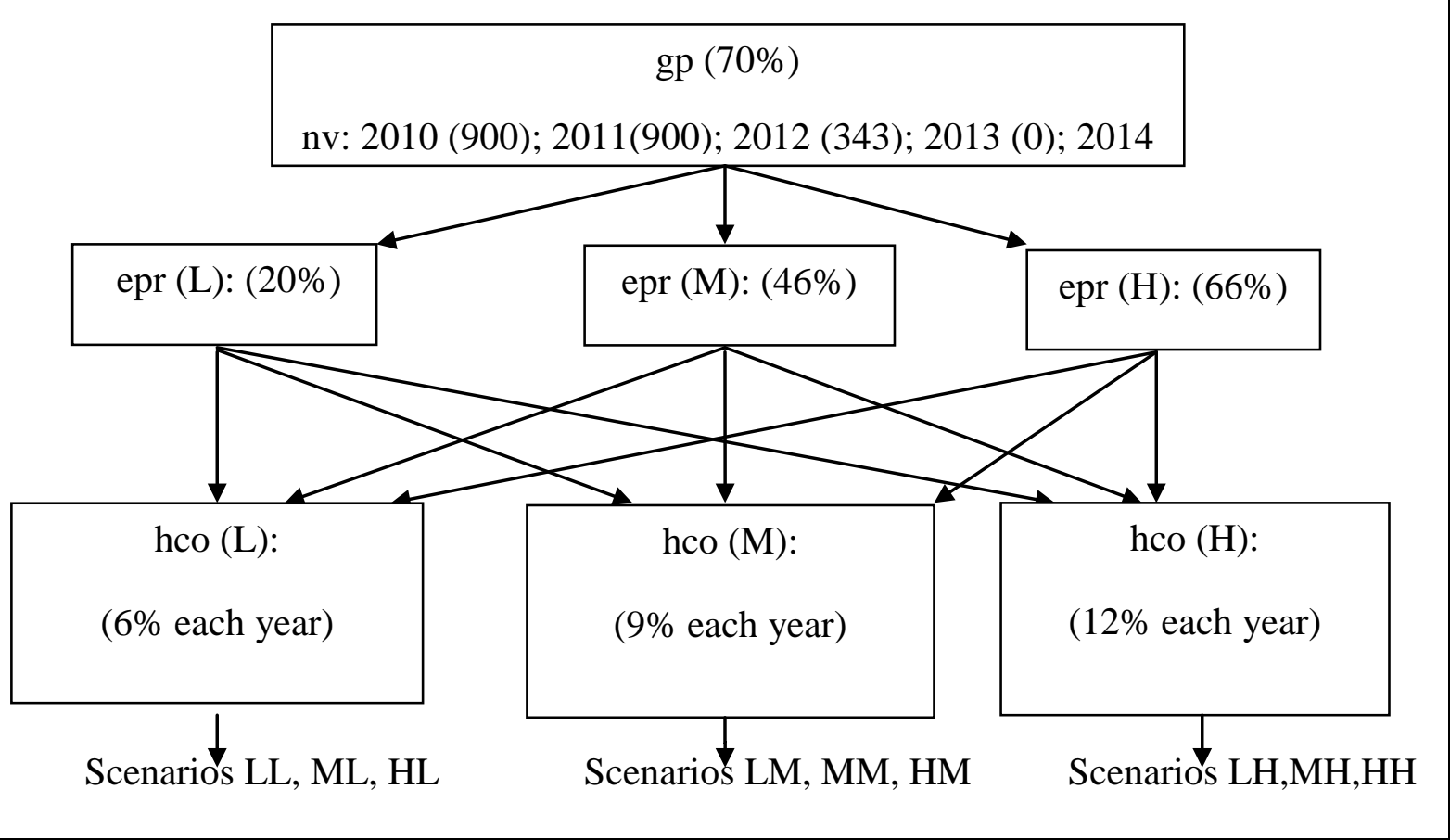

Note: gp, nv, epr and hco denote residential gas price, number of electrified villages, residential electricity price and total household expenditure, respectively. 
Figure 5: Scenarios for residential Electricity Demand
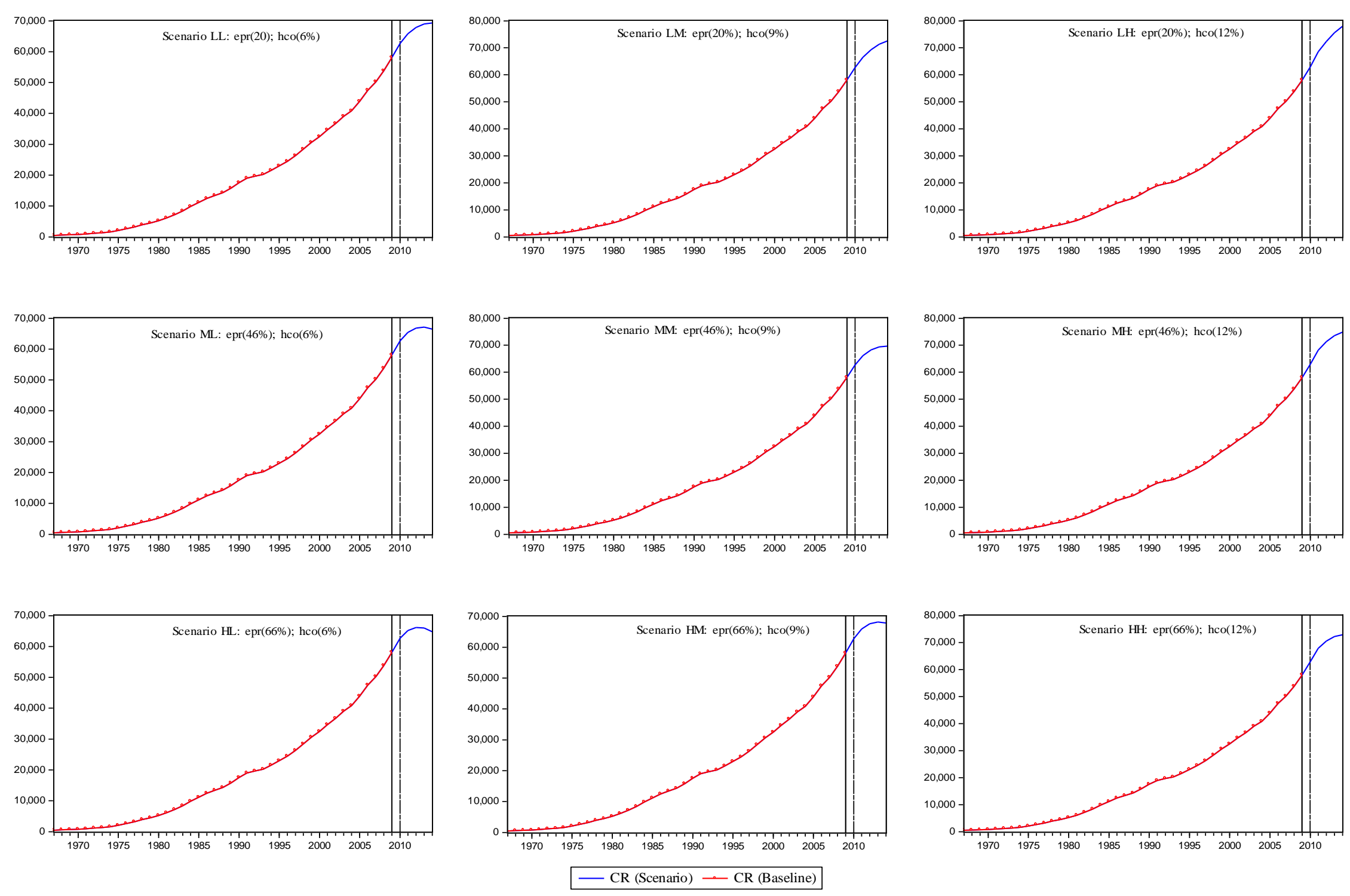
Table 8: Forecast of Residential Electricity Demand

\begin{tabular}{|c|c|c|c|c|c|c|c|c|c|c|c|c|c|c|c|c|}
\hline \multirow{2}{*}{$\begin{array}{c}\text { Scenarios } \\
\text { Year }\end{array}$} & LL & \multicolumn{2}{|c|}{ LM } & \multicolumn{2}{|c|}{ LH } & \multicolumn{2}{|c|}{ ML } & \multicolumn{2}{|c|}{ MM } & \multicolumn{2}{|c|}{$\mathrm{MH}$} & \multicolumn{2}{|c|}{$\mathrm{HL}$} & \multicolumn{2}{|c|}{$\mathrm{HM}$} & \multirow{2}{*}{$\begin{array}{c}\mathrm{HH} \\
\text { GWh \% }\end{array}$} \\
\hline & GWh \% & GWh & $\%$ & GWh & $\%$ & GWh & $\%$ & GWh & $\%$ & GWh & $\%$ & GWh & $\%$ & GWh & $\%$ & \\
\hline 2009 & 58.1 & 58.1 & & 58.1 & & 58.1 & & 58.1 & & 58.1 & & 58.1 & & 58.1 & & 58.1 \\
\hline 2010 & 62.78 & 62.8 & 8 & 63.0 & 8 & 62.7 & 8 & 62.8 & 8 & 63.0 & 8 & 62.7 & 8 & 62.8 & 8 & 63.08 \\
\hline 2011 & $65.8 \quad 5$ & 66.5 & 6 & 68.5 & 9 & 65.4 & 4 & 66.1 & 5 & 68.1 & 8 & 65.1 & 4 & 65.9 & 5 & 67.98 \\
\hline 2012 & 67.83 & 69.3 & 4 & 72.4 & 6 & 66.8 & 2 & 68.3 & 3 & 71.3 & 5 & 66.2 & 2 & 67.6 & 3 & 70.64 \\
\hline 2013 & 69.0 & 71.3 & 3 & 75.6 & 4 & 67.1 & 1 & 69.4 & 2 & 73.5 & 3 & 66.0 & 0 & 68.2 & 1 & 72.22 \\
\hline 2014 & 69.2 & 72.6 & 2 & 78.0 & 3 & 66.5 & -1 & 69.7 & 0 & 74.8 & 2 & 64.7 & -2 & 67.8 & -1 & 72.91 \\
\hline 2014 & & & & & & & & & & & & & & & & \\
\hline $\begin{array}{c}\text { VS. } \\
2009\end{array}$ & -- 19 & -- & 25 & -- & 34 & -- & 14 & -- & 20 & -- & 29 & -- & 11 & -- & 17 & $--\quad 25$ \\
\hline
\end{tabular}


Table 9: Residential Electricity Demand under MH Scenario

\begin{tabular}{|c|c|c|c|}
\hline Years & Demand & Annual growth rate (\%) & $\begin{array}{c}\text { Growth rate compared } \\
\text { to } 2009(\%)\end{array}$ \\
\hline 2010 & 62,970 & 8.4 & 8.4 \\
\hline 2011 & 68,137 & 8.2 & 17.3 \\
\hline 2012 & 71,298 & 4.6 & 22.7 \\
\hline 2013 & 73,540 & 3.1 & 26.6 \\
\hline 2014 & 74,849 & 1.8 & 28.8 \\
\hline 2015 & 75,718 & 1.2 & 30.3 \\
\hline 2016 & 79,047 & 4.4 & 36.1 \\
\hline 2017 & 83,654 & 5.8 & 44.0 \\
\hline 2018 & 89,430 & 6.9 & 53.9 \\
\hline 2019 & 96,374 & 7.8 & 65.9 \\
\hline 2020 & 104,548 & 8.5 & 79.9 \\
\hline
\end{tabular}




\section{Appendix A}

The utility function of a consumer $(U)$ in any given time period is defined as:

$U=U\left(Q_{e}, Q_{s}, Q_{x}, G\right)$

Where $Q_{e}$, and $Q_{s}$, are the quantity of electricity and its substitute goods, respectively, $Q_{x}$ is the quantity of other goods, and $G$ is geographical and demographic features which define the household's preference (Filippini, 1999). The household consumer is assumed to maximize the utility subject to a budget constraint, so:

$L=U\left(Q_{e}, Q_{s}, Q_{x}, G\right)-\lambda\left(P_{e} Q_{e}+P_{s} Q_{s}+P_{x} Q_{x}-Y\right)$

Where $\lambda$ is the lagrangian multiplier, $P_{e}, P_{s}$ and $P_{x}$ are the prices of $Q_{e}, Q_{s}$ and $Q_{x}$, respectively and $Y$ is household consumer income.

The assumption is that prices and income are fixed in a given period. Taking the first derivative of Equation (a.2) with respect to $Q_{e}, Q_{s}, Q_{x}$ and $\lambda$ results in a system of equations. By solving the equations the demand for electricity and other commodities is obtained. The electricity demand function $\left(Q_{e}\right)$ of a single consumer per time period is given by:

$Q_{e}=f\left(P_{e}, P_{s}, P_{x}, Y, G\right)$

The total consumption of electricity by all the consumers $(Q)$ can be derived by summing up the individual quantities. Therefore, the demand for $n$ consumers in a given period is:

$Q=\sum_{i=1}^{n} Q_{e i}=\sum_{i=1}^{n} f_{i}\left(P_{e}, P_{s}, P_{X}, Y, G\right)$

If the demand function is characterised by constant elasticity of demand, then the total electricity demand of $n$ consumers at time $t$ is:

$Q_{t}=P_{e t}^{\alpha} P_{s t}^{\beta} P_{x t}^{\tau} Y_{t}^{\gamma} G_{t}^{\delta}$ 
Taking the log transformation of Equation (a.5) the demand function can be given by:

$$
q_{t}=\alpha p_{e t}+\beta p_{s t}+\tau p_{x t}+\gamma y_{t}+\delta g_{t}
$$

